\title{
Alina Mieszkalnictwo społeczne w Polsce - Muzioł-Węcławowicz wyzwania i ograniczenia
}

Social housing in Poland: challenges and barriers

This article explores the need for more intensive development of social rental housing in Poland, especially communal rental housing and social rental housing provided by Social Housing Associations (TBSs). The first section briefly examines the terminology and addresses the main challenges in Polish housing in accordance with the goals of the housing policy programmes. The second section reports on the recent trends in social rental housing. The third section presents selected issues of the recent development of Polish social rental housing. Further, the author tries to evaluate the need for new housing construction by local authorities and by TBSs. Due to the lack of reliable information, the required amount of new housing can only be approximated indirectly. In the next section, she presents legislative initiatives regulating and supporting social rental housing, especially in terms of modifying financial instruments. The final section contains an assessment of progress in social rental housing and proposals for further reforms in Polish housing policy.

\begin{tabular}{r|l}
\hline DOI & https://doi.org/10.31268/StudiaBAS.2021.18 \\
\hline Słowa kluczowe & $\begin{array}{l}\text { polityka mieszkaniowa w Polsce, społeczne mieszkalnictwo czynszowe } \\
\text { W Polsce, towarzystwa budownictwa społecznego (TBS), preferencyjne } \\
\text { finansowanie zwrotne, Fundusz Dopłat }\end{array}$ \\
\hline Keywords & $\begin{array}{l}\text { housing policy in Poland, social rental housing in Poland, Social } \\
\text { Housing Associations, preferential housing loans, Subsidy Fund }\end{array}$ \\
\hline O autorce & $\begin{array}{l}\text { doktor nauk geograficznych, Instytut Rozwoju Miast i Regionów • } \\
\text { alina.muziol@wp.pl • ORCID 0000-0001-6819-3644 }\end{array}$ \\
\hline
\end{tabular}

Autorka serdecznie dziękuje p. dr. Kamilowi Nowakowi za opracowanie wykresu zasobów TBS (wykres 3) oraz sporzq̨dzenie mapy rozmieszczenia mieszkań w zasobach TBS (rysunek 1) i p. Wojciechowi Danielowi za udostępnienie danych o wynagrodzeniach, stawkach czynszu i kosztach w zasobach Tarnowskiego TBS (wykres 4).

\section{Wstęp}

Z perspektywy społeczeństwa oraz indywidualnych potrzeb wielu gospodarstw domowych brak samodzielnego mieszkania lub nieodpowiednie warunki mieszkaniowe należą do czynników ograniczających rozwój i zmniejszających satysfakcję z życia. Sytuacja mieszkaniowa Polaków systematycznie się poprawia, ale warunki lokalowe i dostępność mieszkań w Polsce wciąż należą do najgorszych w Unii Europejskiej. Obok ilościowych problemów wynikających z braku mieszkań i ze złego standardu technicznego znacznej części starszych zasobów mieszkaniowych wyraźnie rysuje się także problem braku mieszkań dostępnych cenowo dla słabszych ekonomicznie i społecznie grup ludności, przede wszystkim ludzi młodych. Z badań Urzędu Statystycznego w Warszawie wynika, że 36\% osób (43\% mężczyzn i 26\% kobiet) w wieku od 
25 do 34 lat stanowią tzw. gniazdownicy, czyli osoby mieszkające z rodzicami, nieposiadające współmałżonka i niebędące rodzicem¹.

W niniejszej pracy zwrócono uwagę na konieczność funkcjonowania społecznego sektora mieszkaniowego i jego odpowiednią do potrzeb skalę. W artykule zweryfikowano tezę o niedorozwoju sektora mieszkalnictwa społecznego w Polsce. W kontekście zmian polityki mieszkaniowej państwa podano dane o liczbie mieszkań w sektorze społecznym, przedstawiono ocenę zmian prawnych w zakresie finansowania mieszkalnictwa społecznego oraz rekomendacje dotyczące kierunków poprawy dostępności mieszkań. Zaproponowano długofalową strategię zdecentralizowanej polityki mieszkaniowej, silnie wspieranej finansowo i prawnie przez państwo. Podstawą strategii powinno być przyjęcie założenia, że mieszkalnictwo społeczne jest ważnym elementem gospodarki miast, warunkującym dostępność mieszkań. Miasta powinny opierać swoje działania w zakresie mieszkalnictwa społecznego na dwóch filarach (formach inwestycyjnych) - inwestycjach własnych i inwestycjach towarzystw budownictwa społecznego (TBS).

\section{Mieszkalnictwo społeczne}

Mieszkalnictwo rozpatruje się jako prywatną (komercyjną) lub społeczną (publiczną) działalność gospodarczą. Mieszkania tworzone i/lub utrzymywane z pomocą władz publicznych mogą funkcjonować w sektorze zarówno własnościowym, jak i czynszowym, prywatnym oraz publicznym. W tym miejscu będzie mowa wyłącznie o społecznym sektorze czynszowym jako dominującym w polskiej polityce mieszkaniowej.

Na poziomie ogólnym można przyjąć, że pojęcia „mieszkanie dostępne”, „mieszkanie przystępne”, „mieszkanie społeczne” są zbliżone. Pierwsze zdefiniowano ogólnie jako „[...] zasoby mieszkaniowe przeznaczone dla osób, które mają problem z zaspokojeniem swoich potrzeb mieszkaniowych"2. Kiedy z języka angielskiego tłumaczy się termin affordable housing, mowa o „mieszkaniach dostępnych” lub „mieszkaniach przystępnych”. Mieszkania dostępne to mieszkania o kosztach dostępu niższych od rynkowych, np. niskich stawkach czynszu, wynikających m.in. z systemów wsparcia użytkowników mieszkań (np. dodatki mieszkaniowe) lub z rozwiązań systemowych (np. formuła inwestora non profit lub limitowanego zysku, ulgi podatkowe). Mieszkania społeczne są elementem systemu mieszkań dostępnych, bardziej regulowanym i kierowanym do gospodarstw o niższych dochodach. Społeczny sektor mieszkaniowy jest definiowany przez zasady finansowania i udostępniania mieszkań oraz podmioty uczestniczące w jego funkcjonowaniu. Istotną rolę w kształtowaniu społecznego sektora mieszkaniowego odgrywają samorządy gminne, które realizują część zadań obligatoryjnych, na mocy ustaw³, i część zadań dobrowolnych wynikających z kompetencji samorządu gminnego.

1 Urząd Statystyczny w Warszawie, Pokolenie gniazdowników w Polsce. Prace eksperymentalne, Warszawa 2020.

2 A. Twardoch, System do mieszkania. Perspektywy rozwoju dostępnego budownictwa mieszkaniowego, Bęc Zmiana!, Warszawa 2019, s. 40.

3 Podstawowe regulacje stanowią: ustawa z dnia 8 marca 1990 r. o samorządzie gminnym (Dz.U. 2020, poz. 713, ze zm.), ustawa z dnia 21 czerwca 2001 r. o ochronie praw lokatorów, mieszkaniowym zasobie gminy i o zmianie Kodeksu cywilnego (Dz.U. 2020, poz. 611, ze zm.), ustawa z dnia 21 czerwca 2001 r. o do- 
W praktyce mieszkalnictwo społeczne funkcjonuje przede wszystkim w miastach, a zasoby tego typu i zapotrzebowanie na nie koncentrują się w miastach dużych. W Polsce wyraźne są zróżnicowania regionalne - w zachodniej części kraju jest więcej zasobów komunalnych i zasobów TBS niż w części wschodniej, również w średnich i mniejszych miastach.

Gminy są wspierane programami polityki mieszkaniowej państwa. O społecznym budownictwie czynszowym można mówić, gdy są spełnione następujące warunki:

- dostęp do lokali mieszkalnych odbywa się na zasadach nierynkowych, na podstawie kryteriów określonych przez władze publiczne,

- na etapie budowy, przebudowy lub użytkowania budynków podmioty realizujące inwestycje korzystają ze wsparcia ze środków publicznych,

- jest realizowane przez podmioty, których głównym celem działania nie jest osiąganie zysków ${ }^{4}$.

Podobnie można definiować społeczny sektor mieszkaniowy i najem społeczny. W tej kategorii mieszczą się czynszowe zasoby mieszkaniowe:

- gmin (i innych jednostek samorządu terytorialnego),

- towarzystw budownictwa społecznego - TBS $^{5}$ (publicznych i prywatnych),

- zakładów pracy i Skarbu Państwa - te ostatnie często są udostępniane na podstawie specjalnych przepisów branżowych,

a także:

- mieszkania chronione, funkcjonujące w systemie pomocy społecznej, udostępniane na podstawie decyzji administracyjnej, ale wypełniające warunki zasobu społecznego,

- mieszkaniowe zasoby czynszowe innych podmiotów, np. należące do organizacji charytatywnych.

W Polsce zasadniczy trzon mieszkalnictwa społecznego stanowią mieszkania gminne (komunalne) oraz mieszkania będące w zasobach towarzystw budownictwa społecznego. Mieszkania komunalne są wynajmowane przez gminy na zasadach najmu socjalnego lub najmu standardowego komunalnego, na czas nieoznaczony ${ }^{6}$. Z zasobów towarzystw budownictwa społecznego,

datkach mieszkaniowych (Dz.U. 2019, poz. 2133, ze zm.). W kompetencjach gmin leży po części większość ustaw regulujących sferę mieszkaniową.

4 Definicja zawarta w ustawie z dnia 9 października 2015 r. o rewitalizacji, w jej pierwotnym brzmieniu (art. 27 ust. 1, Dz.U. 2015, poz. 1777).

5 Zasady funkcjonowania towarzystw budownictwa społecznego, w tym reguły preferencyjnego finansowania i udostępniania mieszkań, określono w ustawie z dnia 26 października 1996 r. o niektórych formach popierania budownictwa mieszkaniowego (Dz.U. 2019, poz. 2195, ze zm.). Na mocy ustawy z dnia 10 grudnia 2020 r. o zmianie niektórych ustaw wspierających rozwój mieszkalnictwa (Dz.U. 2021, poz. 11) nazwę „towarzystwo budownictwa społecznego" (TBS) zamieniono na "społeczną inicjatywę mieszkaniową" (SIM), bez zmian w zakresie i zasadach działania tych podmiotów. Od 19 stycznia 2021 r. nowe podmioty są określane jako społeczne inicjatywy mieszkaniowe (SIM). Spółki utworzone przed tą datą mogą nadal używać nazwy TBS. Dla uproszczenia w opracowaniu będą używane wyłącznie: nazwa "towarzystwo budownictwa społecznego" i skrót TBS dla obydwu kategorii podmiotów.

6 Termin „standardowe mieszkania komunalne” odnosi się do części zasobów komunalnych wynajmowanych na czas nieoznaczony, dla odróżnienia od drugiej formy najmu w zasobach komunalnych - najmu socjalnego (dla osób biednych i z orzeczoną eksmisją). 
tworzonych od 1996 r., korzystają gospodarstwa domowe o dochodach na limitowanym górnym poziomie. Charakteryzują się regulacją czynszów w postaci górnego limitu stawki, powiązanego ze wskaźnikiem kosztów odtworzeniowych. Kieruje się je do osób będących w luce czynszowej, czyli mających dochody za wysokie, by ubiegać się o najem mieszkania komunalnego, a zarazem za niskie, by wynajmować lub kupić mieszkanie na rynku.

Według stanu na koniec 2018 r. w Polsce było 14,6 mln mieszkań7 , z tego 78,9\% ogółu zasobów stanowiły mieszkania prywatne, 13,9\% to własność spółdzielcza, 5,8\% - własność komunalna, a 0,7\% - własność TBS. Pozostałe 0,7\% to mieszkania zakładów pracy, Skarbu Państwa i innych podmiotów. Dalszą analizą zostaną objęte zasoby społeczne we własności komunalnej i towarzystw budownictwa społecznego. Nie ma obecnie danych o aktualnej wielkości zasobu spółdzielczych mieszkań lokatorskich, które po części spełniają kryteria zasobów społecznych. Zakłady pracy i Skarb Państwa zarządzają nieznacznymi zasobami.

Po 1989 r. polityka mieszkaniowa państwa nie miała priorytetu, a rządowe programy polityki mieszkaniowej były realizowane w niewielkim stopniu. Zdarzało się, że wprowadzano rozwiązania sprzeczne z dokumentami strategicznymi. Bezpośrednie wydatki budżetu państwa na cele mieszkaniowe były i nadal są na niskim poziomie, a ich struktura nie świadczy o preferowaniu instrumentów służących rozwojowi społecznego sektora czynszowego. Na początku transformacji przyjęto rynkowy model polityki mieszkaniowej ${ }^{8}$. Warto wskazać, że w pierwszym programie polityki mieszkaniowej z 1993 r. uznano, iż najbliższym celem polityki mieszkaniowej musi być stworzenie podstaw prawnych, ekonomicznych i organizacyjnych rynkowej gospodarki mieszkaniowej, ale na zasadach społecznie akceptowanych ${ }^{9}$. Jednym z programów nowej polityki był wdrożony w 1995 r. program społecznego budownictwa czynszowego, oparty na odrębnym systemie finansowania i kredytowania. Problemem było nie tyle niezauważanie potrzeb rozwoju mieszkalnictwa społecznego, ile bardzo niskie wydatki rządowe na ten sektor i zmienność koncepcji wspierania rodzin w uzyskaniu samodzielnego mieszkania. Silniej wspomagano nowe idee rządowe (np. program Mieszkanie Plus PFR Nieruchomości), a także programy umożliwiające uzyskanie mieszkania na własność (np. Mieszkanie dla Młodych).

Decyzje podejmowane w pierwszych latach transformacji nie tworzyły warunków do rozwoju komunalnego sektora czynszowego. Do 2004 r. utrzymywano kontrolę nad czynszami, a niskie dochody i bezrobocie nie sprzyjały ekonomizacji stawek czynszu. Promowano prywatyzację zasobów komunalnych, a zatem przenoszenie praw własności na użytkowników mieszkań, które rozpoczęło się w Polsce już w latach 70. XX w.

Pewne elementy polityki mieszkaniowej w okresie transformacji w Polsce były wartościowe i prekursorskie na tle państw Europy Środkowo-Wschodniej. Mianowicie wcześnie stworzono regulacje dotyczące wspólnot mieszkaniowych oraz podstawy komercyjnego rynku kredytów

7 Dane Banku Danych Lokalnych Głównego Urzędu Statystycznego. Dane zawarte w tekście, o ile nie podano innego źródła, pochodzą z Banku Danych Lokalnych GUS lub z publikacji GUS dotyczących gospodarki mieszkaniowej.

8 P. Jarecki, E. Kucharska-Stasiak, A. Miklaszewska, K. Olbińska, B. Wieteska-Rosiak, M. Załężna, Optymalne programy wsparcia budownictwa mieszkaniowego. Analiza efektywności, Warszawski Instytut Bankowości, Łódź 2020.

9 Rada Ministrów, Założenia polityki mieszkaniowej państwa, Warszawa 1993, s. 1. 
mieszkaniowych hipotecznych i budowlanych. Wprowadzono także pośrednie wsparcie inwestycji mieszkaniowych obywateli w formie ulg podatkowych oraz utworzono system organizacyjny i finansowy społecznego budownictwa czynszowego realizowanego przez towarzystwa budownictwa społecznego. Do złych stron polityki mieszkaniowej państwa po 1990 r. można zaliczyć nerwowość w poszukiwaniu instrumentów finansowych i krótki czas ich obowiązywania oraz brak właściwego, dostosowanego do potrzeb finansowania sektora społecznego. Po 1989 r. wykorzystano właściwie wszystkie rodzaje instrumentów finansowych - ulgi podatkowe, preferencyjne stawki podatku VAT, preferencyjne kredyty, dotacje, dopłaty do oprocentowania kredytów, dopłaty do wkładu własnego, premie. W większości przypadków wspomniane instrumenty funkcjonowały krótko, co przy niskich wydatkach budżetowych sprawiało, że efekty poszczególnych programów były niezadowalające. Znaczna część bezpośrednich wydatków budżetu państwa na cele mieszkaniowe dotyczyła wspierania wcześniejszych inwestycji (premie oszczędnościowe, wykup odsetek od kredytów na mieszkania spółdzielcze).

Krajowy Fundusz Mieszkaniowy (KFM) prowadzony przez Bank Gospodarstwa Krajowego (BGK), kredytujący na zasadach preferencyjnych przedsięwzięcia TBS i spółdzielni mieszkaniowych (SM) w zakresie mieszkań lokatorskich lub na wynajem, rozpoczął działalność w 1996 r. i już pod koniec 2000 r. zabrakło w nim środków na obsługę przyjmowanych wniosków kredytowych. Rozpoczęto biurokratyczne procedury kwalifikacji wstępnych. Efekty inwestycji TBS byłyby o wiele większe, gdyby środki z rządowego programu były szerzej dostępne. W latach 2001-2009 złożono w BGK wnioski kredytowe na kwotę 14 mld zł, ale kwalifikację uzyskały tylko wnioski na sumę 7,4 mld zł (52,7\% formalnie poprawnych aplikacji). Przy braku ograniczeń w kredytowaniu TBS i SM mogłyby w tym czasie zrealizować ok. 163,8 tys. mieszkań, ale kwalifikacje ograniczyły aktywność inwestycyjną do 96,6 tys. mieszkań ${ }^{10}$. Krajowy Fundusz Mieszkaniowy zlikwidowano w 2009 r., choć według ówczesnych prognoz już w 2018 r. mógłby samodzielnie, bez dotacji budżetowych i pożyczek zagranicznych, udzielać ze środków własnych kredytów o wartości ok. 300 mln zł rocznie. Rozwiązanie KFM było oceniane krytycznie ${ }^{11}$, szczególnie przez środowiska samorządowe i reprezentantów TBS. Skutkowało to wygaszeniem preferencyjnego finansowania na pięć lat, w czasie których BGK kredytował sukcesywnie wnioski złożone i zakwalifikowane w 2009 r. i wcześniej. W latach 2011-2016, według danych BGK, zawarto umowy na 65 „starych” kredytów, obejmujących łącznie budowę przez TBS 5,1 tys. lokali mieszkalnych. Nie wiadomo, ile faktycznie powstałoby mieszkań w sytuacji braku limitu kredytowego KFM i utrzymania ciągłości systemu preferencyjnych kredytów. Te ograniczenia zahamowały rozwój społecznego budownictwa mieszkaniowego i wpłynęły na niezbyt przychylny odbiór społeczny inwestycji TBS. Dopiero pod koniec 2015 r. wprowadzono nową formę preferencyjnego finansowania zwrotnego dla TBS i spółek komunalnych niebędących TBS, skrótowo określaną jako finansowanie SBC (społeczne budownictwo czynszowe). Kredyty są udzielane ze środków własnych BGK, a bank na zasadach umownych uzyskuje rekompensatę z tytułu różnicy między rynkowym oprocentowaniem kredytów a tym preferencyjnym.

10 Informacje ze sprawozdań rocznych Krajowego Funduszu Mieszkaniowego.

11 M. Cesarski, Budziet a mieszkalnictwo i budownictwo społeczne w Polsce. Transformacja i perspektywy, „Problemy Polityki Społecznej. Studia i Dyskusje" 2011, nr 15, s. 29-51. 
Szerzej zagadnienia podażowych, popytowych lub mieszanych instrumentów wsparcia mieszkalnictwa ze środków publicznych przedstawiono w pracach: M. Bryxa (2001), P. Lisa (2008), P. Jareckiego, E. Kucharskiej-Stasiak, A. Miklaszewskiej, K. Olbińskiej, B. Wieteski-Rosiak, M. Załężnej (2020), T. Markowskiego, D. Drzazgi, D. Sikory-Fernandez, L. Groeger, J. Danielewicz (2018), A. Muzioł-Węcławowicz (2015) oraz w badaniu wydatków publicznych na mieszkalnictwo $^{12}$. Zagadnieniom mieszkalnictwa społecznego poświęcono raport Obserwatorium Polityki Miejskiej ${ }^{13}$. Szczegółową charakterystykę polityki mieszkaniowej w Polsce w kontekście badań naukowych przedstawił M. Cesarski (2013). Dostępne są również raporty grup eksperckich związanych z rynkiem nieruchomości i raporty ministerialne, np. Stan mieszkalnictwa w Polsce ${ }^{14}$. Ogólnie ocenia się, że w sytuacji wysokiego deficytu mieszkaniowego i niskich dochodów ludności korzystniejszym rozwiązaniem jest wspieranie środkami publicznymi podaży mieszkań dostępnych, przy prowadzeniu spójnej polityki wobec wszystkich sektorów mieszkaniowych. Co więcej, dynamika rozwoju społecznego sektora czynszowego komunalnego i TBS jest oceniana jako niewystarczająca w odniesieniu do potrzeb. Potwierdzają to raporty Najwyższej Izby Kontroli oraz opracowania ewaluacyjne. W podsumowaniu wyników kontroli działania administracji publicznej na rzecz zaspokajania potrzeb mieszkaniowych gospodarstw domowych o niskich dochodach ${ }^{15}$ stwierdzono, że wspomniane działania nie były skuteczne. W kontrolowanych gminach, mimo prowadzonych inwestycji, liczba osób oczekujących na najem mieszkania nadal była wysoka. Brak wyraźnej poprawy sytuacji mieszkaniowej osób uprawnionych do pomocy mieszkaniowej ze strony samorządu jest wskazywany praktycznie we wszystkich badaniach. Program wsparcia mieszkalnictwa na wynajem ze środków Funduszu Dopłat został uznany za skuteczny tylko w ograniczonym zakresie, ponieważ słabo generował przyrost mieszkań dla osób najuboższych, przez co nie przeciwdziałał wykluczeniu społecznemu ${ }^{16}$. W dwóch znaczących ewaluacjach nie uwzględniono programu TBS - w dokumencie Przegląd wydatków publicznych. Polityka wspierajaca mieszkalnictwo (2015) oraz raporcie Optymalne programy wsparcia budownictwa mieszkaniowego. Analiza efektywności (2020). W pierwszym przypadku preferencyjne finansowanie społecznego budownictwa czynszowego było wstrzymane i dlatego nie zostało uwzględnione w dokumencie, autorzy drugiego raportu potraktowali jako odrębne programy finansowanie TBS ze środków KFM oraz finansowanie preferencyjne SBC od 2015 r., ponieważ uznali, że nowy program finansowania społecznego budownictwa czynszowego ma za krótką historię. Finansowanie TBS realizowane do 2009 r. zaliczyli do programów cieszących się dużym powodzeniem, ale państwo je wygasiło ze względu na wysokość kosztów generowanych dla budżetu.

12 Ministerstwo Finansów, Ministerstwo Infrastruktury i Rozwoju, Przeglad wydatków publicznych: Polityka wspierająca mieszkalnictwo, Warszawa 2015 (opracowanie przygotowali eksperci OECD).

13 Mieszkalnictwo społeczne. Raport o stanie polskich miast, red. A. Muzioł-Węcławowicz, K. Nowak, Instytut Rozwoju Miast i Regionów, Warszawa 2018.

14 Ministerstwo Rozwoju, Raport. Stan mieszkalnictwa w Polsce, Warszawa 2020.

15 Najwyższa Izba Kontroli, Działania administracji publicznej na rzecz zaspokajania potrzeb mieszkaniowych gospodarstw domowych o niskich dochodach. Informacja o wynikach kontroli. 16/2020/P/19/033/KIN, Warszawa 2020.

16 Ministerstwo Finansów, Ministerstwo Infrastruktury i Rozwoju, Przegląd wydatków... 
W ostatnich rządowych programach polityki mieszkaniowej zwracają uwagę zgodność wniosków diagnostycznych oraz niskie zaangażowanie faktyczne państwa w realizację przyjętych założeń. W Głównych problemach, celach i kierunkach programu wspierania budownictwa mieszkaniowego do 2020 r. z 2010 r. jako pierwszy cel wskazano likwidację deficytów ilościowych w segmencie lokali socjalnych oraz mieszkań dla osób wymagających innej społecznej pomocy mieszkaniowej. Zapowiedziano koncentrację wydatków budżetowych na budownictwie socjalnym i utrzymanie zasobów mieszkaniowych oraz wprowadzenie rozwiązań umożliwiających kontynuację społecznego budownictwa czynszowego. To ostatnie zrealizowano dopiero pod koniec 2015 r. Polityka państwa z tego czasu kojarzy się przede wszystkim z wysokimi nakładami budżetowymi na programy wspierające własność mieszkaniową: Rodzinę na Swoim i Mieszkanie dla Młodych ${ }^{17}$.

W dokumencie z 2016 r. - Narodowym Programie Mieszkaniowym (NPM) - określono trzy główne cele programu:

- zwiększenie dostępu do mieszkań dla osób o dochodach uniemożliwiających nabycie lub wynajęcie mieszkania na zasadach komercyjnych,

- zwiększenie możliwości zaspokojenia podstawowych potrzeb mieszkaniowych osób zagrożonych wykluczeniem społecznym ze względu na niskie dochody lub szczególnie trudną sytuację życiową,

- poprawę warunków mieszkaniowych społeczeństwa, stanu technicznego zasobów mieszkaniowych oraz zwiększenie efektywności energetycznej.

Mimo deklaracji wsparcia społecznego sektora czynszowego i - w zasadzie - faktycznego zwiększenia wsparcia tego sektora był preferowany, co najmniej do 2019 r., program Mieszkanie Plus PFR Nieruchomości oferujący mieszkania czynszowe o komercyjnych stawkach czynszu ${ }^{18}$. W celu zwiększenia dostępności tych mieszkań uruchomiono, poza NPM, program Mieszkanie na Start dotujący czynsze w pierwszych 15 latach zamieszkiwania w nowo budowanych mieszkaniach czynszowych. Cele NPM nie zostaną jednak zrealizowane - kolejka osób ubiegających się o najem mieszkania komunalnego docelowo w 2030 r. ma zostać zlikwidowana, ponieważ przy aktualnym stanie budownictwa i remontów komunalnych nie jest możliwe zapewnienie oczekującym takich lokali. Co więcej, liczba osób oczekujących na najem mieszkania komunalnego w 2019 r. wzrosła o 1,3 tys. w porównaniu z 2018 r. ${ }^{19}$ Do korzystnych pod względem perspektyw mieszkalnictwa społecznego przekształceń wprowadzonych w ostatnich latach należą: zmiany w zasadach ochrony praw lokatorów mieszkań komunalnych i w zasadach działania Funduszu Dopłat (FD) dotującego budowę oraz - w mniejszej skali - remonty mieszkań na wynajem o dostępnych czynszach, głównie komunalnych, oraz wsparcie finansowe społecznego budownictwa

17 W programie polityki mieszkaniowej rządu z 2010 r. zapowiedziano likwidację pierwszego z wymienionych programów i wspieranie mieszkalnictwa czynszowego. Program Mieszkanie dla Młodych, kontynuujący dopłaty dla kredytobiorców mieszkaniowych, wprowadzono w 2014 r. poza obowiązującą strategią mieszkaniową rządu.

18 Zapowiadano realizację 100 tys. mieszkań do końca 2019 r., ale do końca marca 2021 r. zrealizowano jedynie 1017 mieszkań, w budowie znajdowało się 2451 mieszkań (Ministerstwo Rozwoju, Pracy i Technologii, Efekty rzeczowe pakietu Mieszkanie+ w latach 2016-2020 (stan na 31.03.2021 r.)).

19 Główny Urząd Statystyczny, Gospodarka mieszkaniowa w 2019 r. Informacja sygnalna, Warszawa 2020. 
czynszowego realizowanego przez TBS, w tym w zakresie preferencyjnego finansowania kredytowego przez BGK i dotacji ze środków FD oraz nowego, funkcjonującego od 2021 r. Rządowego Funduszu Rozwoju Mieszkalnictwa (RFRM).

\section{Trendy w budownictwie społecznym}

Do zapewnienia realnego wzrostu dostępności mieszkań dla osób niemogących zaspokoić swoich potrzeb mieszkaniowych na rynku, w szczególności dla ludzi młodych, konieczny jest skokowy wzrost liczby budowanych społecznych mieszkań czynszowych. Liczba mieszkań budowanych w ramach budownictwa komunalnego i TBS powinna wzrosnąć z poziomu 3-4 tys. mieszkań rocznie (po 1-2 tys. lokali w każdym sektorze) na przestrzeni ostatnich pięciu lat (2015-2020) do co najmniej 10 tys. lokali rocznie w latach 2022-2030 w obydwu segmentach. Aktualne rządowe programy wsparcia mieszkalnictwa społecznego mogą umożliwić realizację tego celu, jeśli spełnione zostaną dwa warunki:

- budżet państwa zagwarantuje realizację wszystkich przedsięwzięć zgłaszanych przez gminy i TBS,

- budżety samorządów gminnych będą chronione przed drastycznymi obciążeniami wywołanymi skutkami epidemii COVID-19 i polityką fiskalną państwa.

Realizacja pierwszego warunku mieści się w planach rządowych, natomiast nie została jeszcze skonfrontowana z zapotrzebowaniem wyrażonym w postaci wniosków o dotacje i kredyty preferencyjne ze strony gmin, TBS i innych spółek komunalnych. Trudno będzie gminom współfinansować inwestycje mieszkaniowe, mimo znaczącego zwiększenia dotacji. Po wejściu w życie ustawy z dnia 10 grudnia 2020 r. o zmianie niektórych ustaw wspierających rozwój mieszkalnictwa ${ }^{20}$ znacznie wzrosła wartość wsparcia ze środków Funduszu Dopłat - obecnie pokrywa maks. 80\% kosztów kwalifikowanych. Z kolei realizacje TBS mogą być wspierane przez gminy wyższym, sięgającym maks. 35\% kosztów grantem z FD (na podstawie art. 5 ustawy z dnia 8 grudnia 2006 r. o finansowym wsparciu tworzenia lokali mieszkalnych na wynajem, mieszkań chronionych, noclegowni, schronisk dla bezdomnych, ogrzewalni i tymczasowych pomieszczeń $\left.{ }^{21}\right)$. Gminy mogą też ubiegać się o finansowe wsparcie utworzenia TBS lub przystąpienia do już istniejącego towarzystwa, a także o dotację ze środków Rządowego Funduszu Rozwoju Mieszkalnictwa na realizację inwestycji mieszkaniowej. Budżet funduszu wynosi 1,5 mld zł, obsługuje go Krajowy Zasób Nieruchomości (KZN). Na utworzenie nowego TBS lub objęcie udziałów w istniejącym towarzystwie gmina może otrzymać $3 \mathrm{mln}$ zł, a na realizację nowej inwestycji mieszkaniowej - 10\% wartości inwestycji. Najemcy mieszkań będących w zasobach TBS mogą ubiegać się o dopłaty do czynszu z programu Mieszkanie na Start.

Społeczne budownictwo czynszowe, rozumiane tu, zależnie od kontekstu, albo łącznie - jako komunalne i realizowane przez TBS, albo odrębnie - jako komunalne lub TBS (SBC), współcześnie charakteryzuje się częściowym rozdzieleniem funkcji i formy inwestorskiej, tj. właściciela 
zasobów. Mieszkaniowe zadania gmin mogą być realizowane bezpośrednio przez gminę lub przez jej podmioty zależne - spółki komunalne, w tym specyficzne spółki, jakimi są TBS ${ }^{22}$. Dla towarzystw budownictwa społecznego podstawowymi aktywnościami są: budowa mieszkań czynszowych przeznaczonych dla osób i rodzin średniozamożnych (klasyfikowanych według ustawowych limitów dochodowych, wyższych niż w przypadku mieszkań komunalnych) i zarządzanie nimi, na zasadach określonych w ustawie z dnia 26 października 1995 r. o niektórych formach popierania budownictwa mieszkaniowego ${ }^{23}$, przy wykorzystaniu preferencyjnego finansowania zwrotnego, udzielanego w ramach rządowej polityki mieszkaniowej.

Rzadko zwraca się uwagę, że towarzystwa budownictwa społecznego w wielu miastach, na mocy umów z gminami korzystającymi z grantów Funduszu Dopłat, realizują na zamówienie gminy mieszkania pozostające w zasobie TBS, ale udostępniane najemcom na zasadach obowiązujących przy najmie lokalu z mieszkaniowego zasobu gminy (kryteria dochodowe, umowy najmu na czas nieoznaczony, stawki czynszu dla pełnowartościowych zasobów). Najczęściej gminy wynajmują te lokale od spółki i podnajmują je osobom z kolejki mieszkaniowej. Na tworzenie zasobów lokali mieszkalnych na wynajem, realizowanych przez inwestora innego niż gmina lub związek międzygminny, przysługuje dotacja z FD w wysokości 80\% (do 2020 r. 55\%) kosztów budowy, remontu, przebudowy, zmiany sposobu użytkowania, jeśli wykonawcą jest TBS lub inna spółka z większościowym udziałem gminy (przedsięwzięcia realizowane na podstawie art. 5a wspomnianej wyżej ustawy z dnia 8 grudnia 2006 r.). Do końca 2020 r. zrealizowano łącznie 115 takich przedsięwzięć z 3,2 tys. mieszkań na wynajem o ograniczonym czynszu, dotowanych z FD. Najwięcej mieszkań wybudowały towarzystwa działające na terenie województw: pomorskiego (935), zachodniopomorskiego (776) i kujawsko-pomorskiego (507). W czterech województwach (lubelskim, małopolskim, podlaskim i świętokrzyskim) nie zrealizowano żadnego przedsięwzięcia w tej formule.

Inną formą wsparcia budowy mieszkań czynszowych ze środków FD są granty dla gmin, które zawierają umowy z inwestorami o współpracy i w zamian za przekazanie im środków z grantu zyskują prawo wskazywania najemców spośród swoich mieszkańców uprawnionych do pomocy mieszkaniowej (art. 5 ustawy z dnia 8 grudnia 2006 r.). Ta forma istnieje od 2019 r. i do końca 2020 r. zrealizowano osiem przedsięwzięć, łącznie z 635 mieszkaniami w pięciu województwach (dolnośląskim, pomorskim, śląskim, wielkopolskim i zachodniopomorskim). Formalnie gminy korzystające ze wsparcia FD mogą podejmować współpracę z TBS lub innymi spółkami z większościowym udziałem gminy (art. 5a ustawy z dnia 8 grudnia 2006 r.) lub dowolnymi podmiotami realizującymi przedsięwzięcia mieszkaniowe (art. 5 ustawy z dnia 8 grudnia 2006 r.). Do tej pory jednak w obydwu formach wsparcia uczestniczą wyłącznie TBS.

Inwestycje komunalne i inwestycje TBS mogą zaspokajać potrzeby mieszkaniowe ludzi o skromnych dochodach. Stanowią oni trudną do oszacowania główną grupę osób potrzebujących pomocy mieszkaniowej. W przypadku innych form budowy mieszkań na wynajem na

22 Gmina może też realizować mieszkaniowe zadania własne dzięki wykorzystaniu zasobów innych podmiotów (por. art. 4 ust. 3 ustawy z dnia 21 czerwca 2001 r. o ochronie praw lokatorów, mieszkaniowym zasobie gminy i o zmianie Kodeksu cywilnego (Dz.U. 2020, poz. 611, ze zm.)).

23 Dz.U. 2019, poz. 2195, ze zm. 
zasadach rynkowych - Funduszu Mieszkań na Wynajem i programu Mieszkanie Plus PFR Nieruchomości - są stosowane rynkowe stawki czynszu i jest wymagana tzw. zdolność czynszowa na wyższym poziomie. Takie lokale mogą zatem służyć grupie osób o niezaspokojonych potrzebach mieszkaniowych z wyższymi dochodami. Podstawowe formy mieszkalnictwa społecznego w Polsce, tj. mieszkalnictwo komunalne i TBS, mogą być uzupełnione innymi funkcjonującymi lub zapowiadanymi systemami tworzenia mieszkań dostępnych.

\section{Wybrane aspekty rozwoju społecznego sektora czynszowego}

Samorządy gminne opierają swoje działania w zakresie mieszkalnictwa na własnych lokalnych strategiach i politykach mieszkaniowych. Od 2001 r., kiedy wprowadzono obligatoryjne ustalanie zasad gospodarowania mieszkaniowym zasobem gminy ${ }^{24}$, programy te zdominowały kwestie mieszkalnictwa w gminach. Niemniej gminy, a szczególnie duże miasta, powróciły do szerszego planowania rozwoju mieszkalnictwa na swoim terenie, z uwzględnieniem strategicznych działań na rzecz rozwoju całego sektora, w tym budownictwa rynkowego i społecznego czynszowego. Coraz częściej realizacja funkcji mieszkaniowych miast postrzegana jest nie tylko jako obciążenie budżetowe, lecz także jako działalność prorozwojowa, zwiększająca aktywa miast, dynamizująca lokalne rynki pracy i usług.

Na koniec 2018 r. mieszkaniowy zasób gmin liczył 840,4 tys. mieszkań, a na najem lokali w gminach oczekiwało 149,3 tys. gospodarstw domowych ${ }^{25}$. Efekty nowego budownictwa komunalnego i działań remontowych w zasobach komunalnych od lat są niezadowalające. Średni udział budownictwa komunalnego w latach 1996-2019 wynosił 2\% ogółu mieszkań oddanych do użytku, czyli 16,3 mieszkania komunalnego w przeliczeniu na 10 tys. mieszkańców. Najwięcej mieszkań komunalnych udostępniono najemcom w latach: 2006 (4,5 tys.), 2009 (4,2 tys.), 1997 (3,8 tys.), najmniej zaś, poza 2004 r., w latach 2015-2019 - poniżej 1,8 tys. rocznie. Najlepsze efekty odnotowano w województwach: kujawsko-pomorskim, dolnośląskim i zachodniopomorskim (wykres 1). Przez cały okres po transformacji nowe budownictwo komunalne w skali kraju miało charakter szczątkowy, podobnie jak remonty i modernizacje zasobów komunalnych. Rządowy program bezzwrotnego wsparcia gmin w realizacji budownictwa komunalnego ze środków Funduszu Dopłat, zapoczątkowany w 2007 r., miał służyć przyspieszeniu budowy mieszkań socjalnych ${ }^{26}$, później ewoluował w kierunku wspierania ogółu mieszkań komunalnych. Obecnie środki Funduszu Dopłat są przeznaczane na budowę mieszkań na wynajem o umiarkowanych czynszach, bez wyodrębniania mieszkań socjalnych. Zwiększono także możliwości dofinansowania mieszkań o funkcjach komunalnych realizowanych przez inne podmioty na zlecenie gminy. W latach 2007-2020 powstało łącznie 16,9 tys. mieszkań komunalnych wspieranych dotacjami

24 Wieloletnie programy gospodarowania mieszkaniowym zasobem gminy (WPGMZG) wprowadzono ustawą z dnia 21 czerwca 2001 r. o ochronie praw lokatorów, mieszkaniowym zasobie gminy i o zmianie Kodeksu cywilnego (Dz.U. 2020, poz. 611, ze zm.). 
Wykres 1. Mieszkania komunalne oddane w latach 1996-2019 w przeliczeniu na 10 tys. mieszkańców

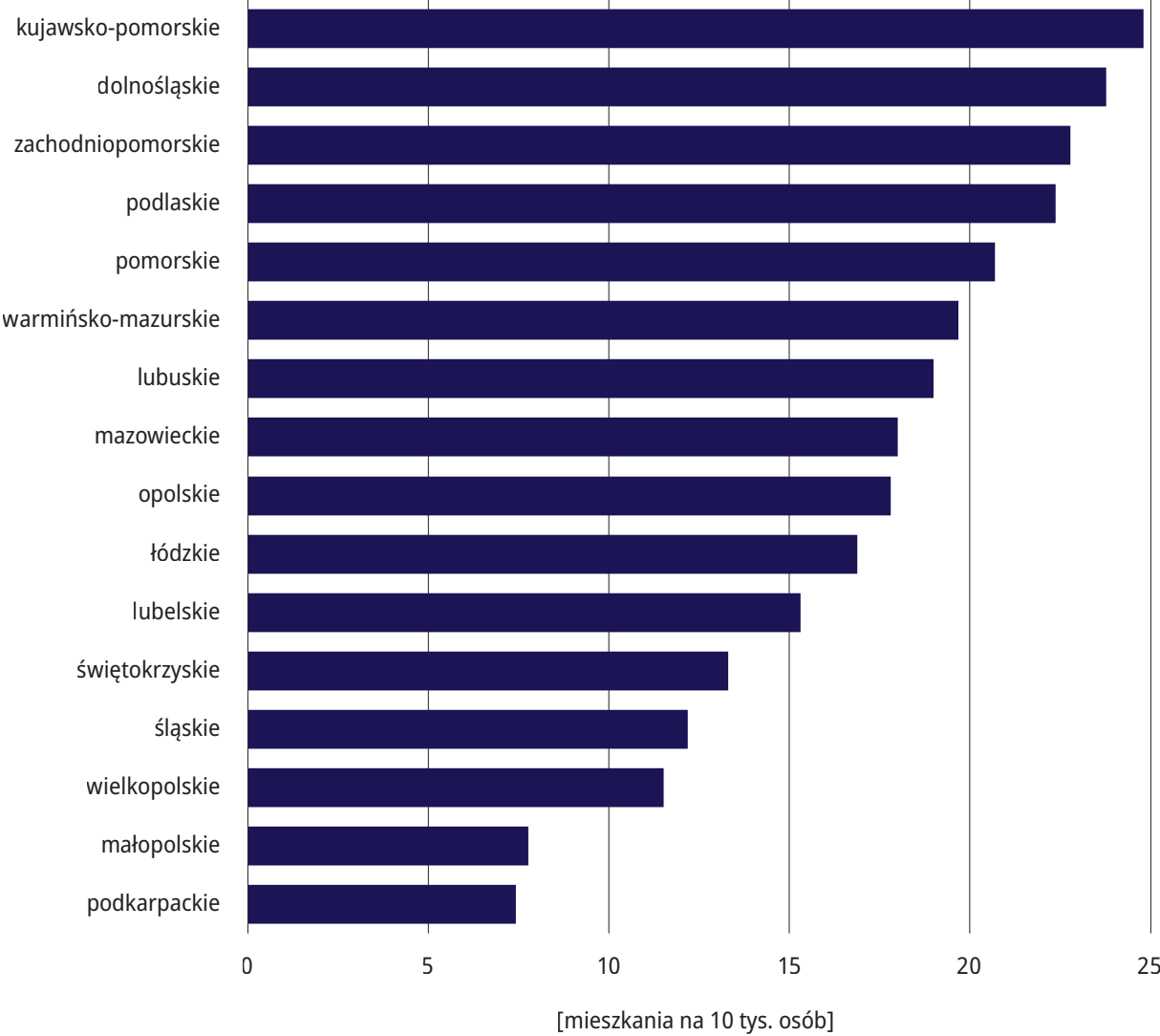

Źródło: obliczenia własne na podstawie danych z Banku Danych Lokalnych Głównego Urzędu Statystycznego.

ze środków FD (wykres 2). Najwięcej takich lokali wybudowano w województwach: śląskim i mazowieckim (po 2,3 tys.), a także dolnośląskim (1,7 tys.). Mimo że gminy są głównym beneficjentem Funduszu Dopłat (98\% ogółu finansowanych przedsięwzięć, 96,7\% łącznej wartości dofinansowania), oferta FD wsparła ok. 50\% mieszkań komunalnych wybudowanych w latach 2007-2019. Również w przypadku tego programu środki budżetowe przekazywane do FD nie zawsze wystarczały na dotowanie wszystkich zgłaszanych projektów.

Część gmin miejskich prowadzi politykę nieangażowania się bezpośrednio jako inwestor i ceduje zadania na towarzystwa budownictwa społecznego lub inne spółki komunalne ${ }^{27}$. Oczekuje się, że znaczący wzrost dopłat, do 80\% kosztów przedsięwzięć, przyczyni się do zwiększenia

27 Por. dane o przedsięwzięciach realizowanych przez TBS z udziałem grantu z FD przekazywanego gminom współpracującym z towarzystwami. TBS mogą też, przy niższym wykorzystaniu kredytu i większym wkładzie własnym, realizować mieszkania o niższym czynszu, np. na poziomie 3\% wartości odtworzeniowej rocznie. 


\section{Wykres 2. Mieszkania komunalne wybudowane w latach 2007-2020 z udziałem dotacji z Fun- duszu Dopłat, w przeliczeniu na 10 tys. mieszkańców}

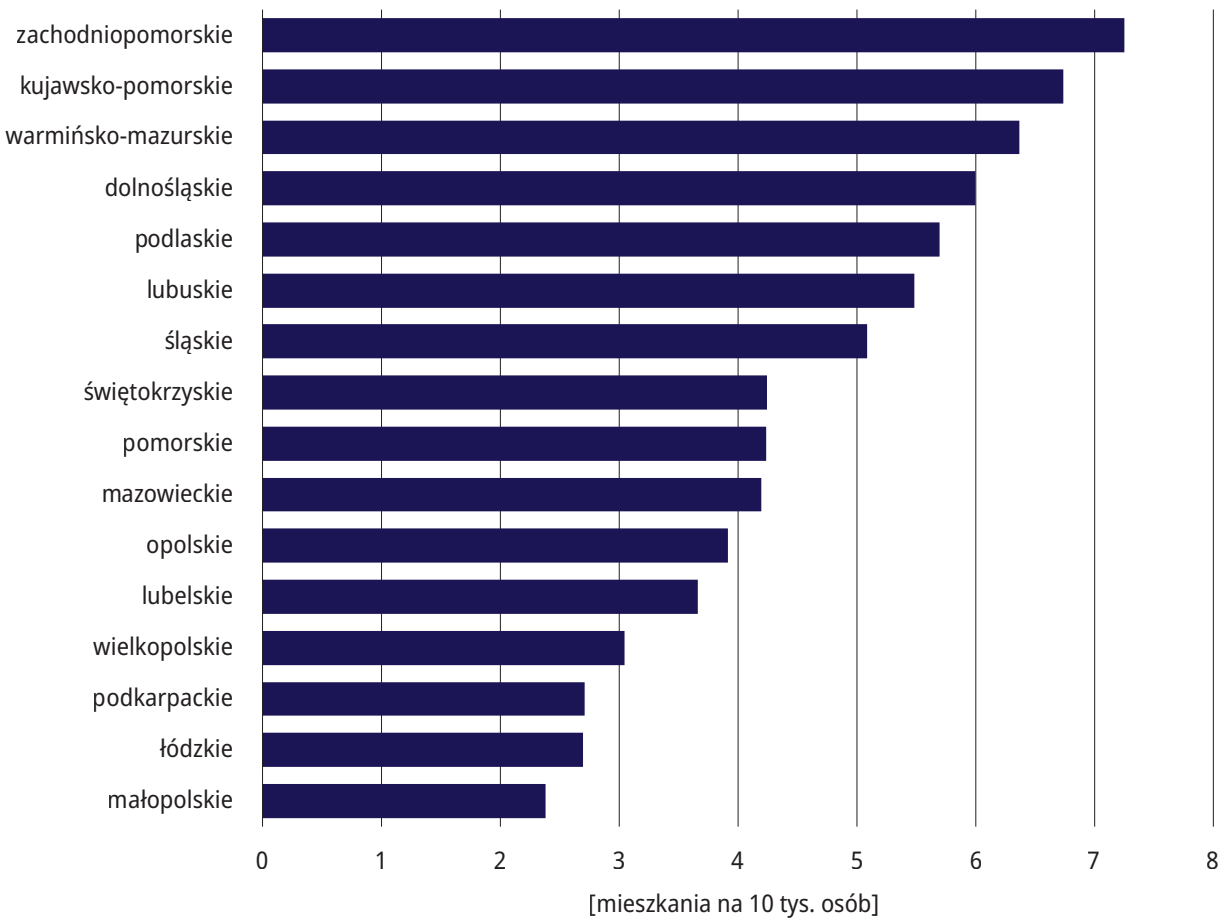

Źródło: obliczenia własne na podstawie danych BGK.

liczby mieszkań komunalnych i mieszkań we własności innych podmiotów zależnych od gmin. Te lokale formalnie nie tworzą mieszkaniowego zasobu gminy, ale są udostępniane na zasadach obowiązujących w tym zasobie (lub zbliżonych).

Zasoby mieszkaniowe TBS na koniec 2018 r. określono na 102,3 tys. mieszkań. W latach 2015-2019 TBS wybudowały 8,1 tys. mieszkań (0,9\% ogółu). Zauważalne są różnice między wolumenem mieszkań w zasobach TBS i mieszkań wybudowanych przez TBS z udziałem preferencyjnego finansowania kredytowego w ramach rządowego programu popierania budownictwa czynszowego. Według danych BGK od 1996 do końca 2020 r. udzielono towarzystwom kredytów na realizację 88,1 tys. mieszkań28 ${ }^{28}$ z tego 86 tys. zostało oddanych do użytku (wykres 3 i rysunek 1). Różnicę stanowią zasoby TBS pozyskane w drodze aportu rzeczowego, wybudowane z wykorzystaniem dotacji dla gmin ze środków Funduszu Dopłat lub na zasadach komercyjnych. Z preferencyjnego kredytu BGK korzystały również spółdzielnie mieszkaniowe, budujące miesz-

28 Informacje BGK o kredytowaniu społecznego budownictwa czynszowego są raportowane na podstawie bieżącej ewidencji portfela kredytowego, stąd dane podawane w różnych terminach mogą nieznacznie się różnić. 


\section{Wykres 3. Zasoby mieszkań TBS wybudowanych z wykorzystaniem preferencyjnego kredy- towania w latach 1996-2020}

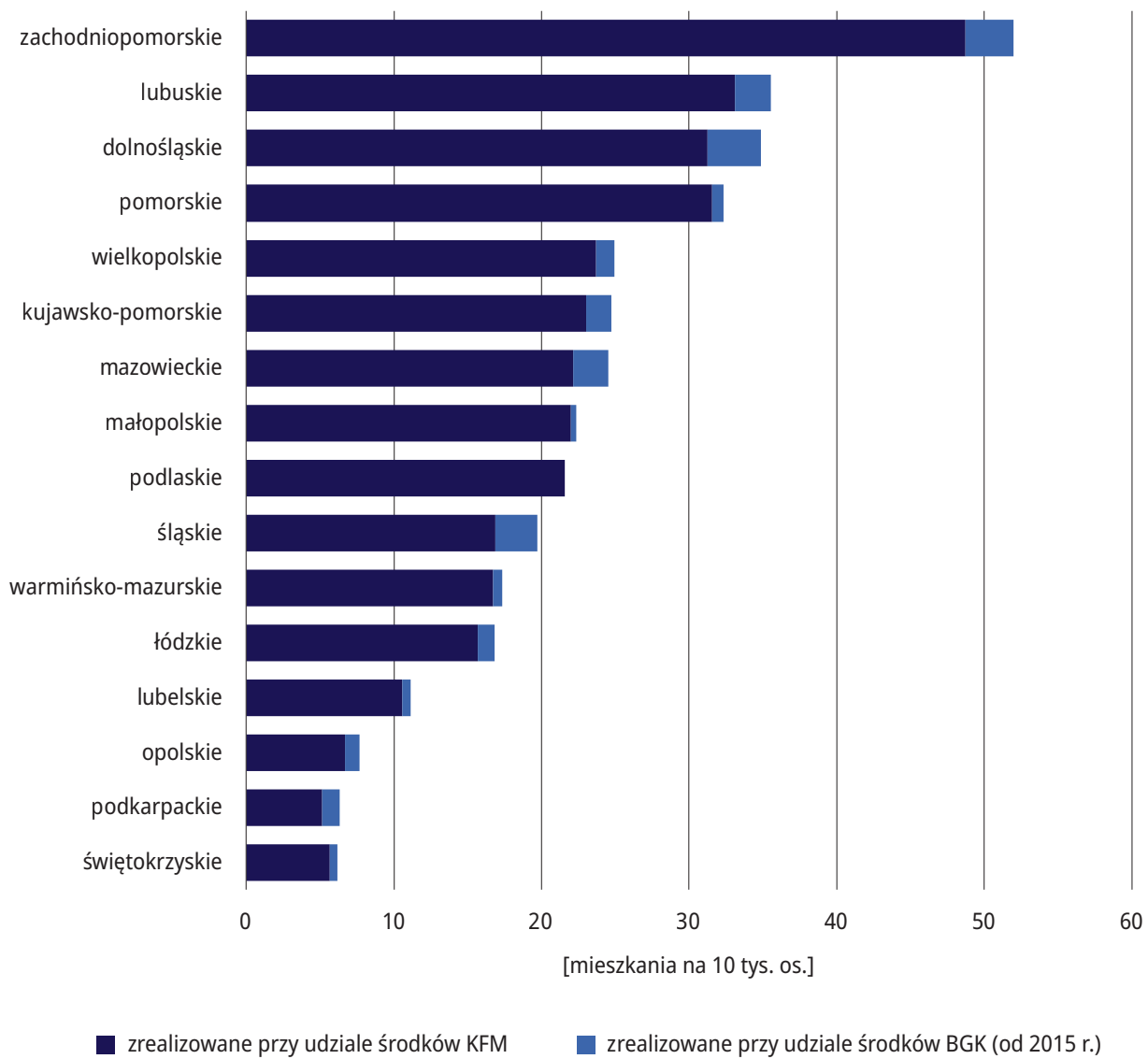

Źródło: opracowanie K. Nowaka na podstawie danych Banku Gospodarstwa Krajowego (dane będące podstawą opracowania wykresu 3 i rysunku 1 uwzględniają również kilka przedsięwzięć realizowanych po 2015 r. przez podmioty inne niż towarzystwa budownictwa społecznego; BGK nie udostępnia wykazów kredytobiorców, lecz jedynie sumaryczne dane według lokalizacji inwestycji).

kania lokatorskie lub na wynajem. W latach 1997-2010 bank udzielił spółdzielniom mieszkaniowym 417 kredytów na budowę 17,2 tys. mieszkań.

Atutem społecznego budownictwa czynszowego w formule TBS jest znaczna liczba specjalistycznych podmiotów funkcjonujących w wielu miastach i kilku gminach wiejskich. Do 2018 r. kredyty na społeczne budownictwo czynszowe zaciągnęły 223 TBS. 84,2\% ogółu mieszkań zbudowały towarzystwa gminne (gminy mają w nich 100\% udziałów lub są udziałowcami większościowymi) ${ }^{29}$, a 15,8\% - towarzystwa prywatne (ze 100-procentowym udziałem podmio-

29 Udziałowcem jednego towarzystwa jest Skarb Państwa. 
Rysunek 1. Gminy, na których terenie powstały mieszkania czynszowe wybudowane przez TBS z wykorzystaniem preferencyjnego finansowania kredytowego z BGK w latach 1996-2020

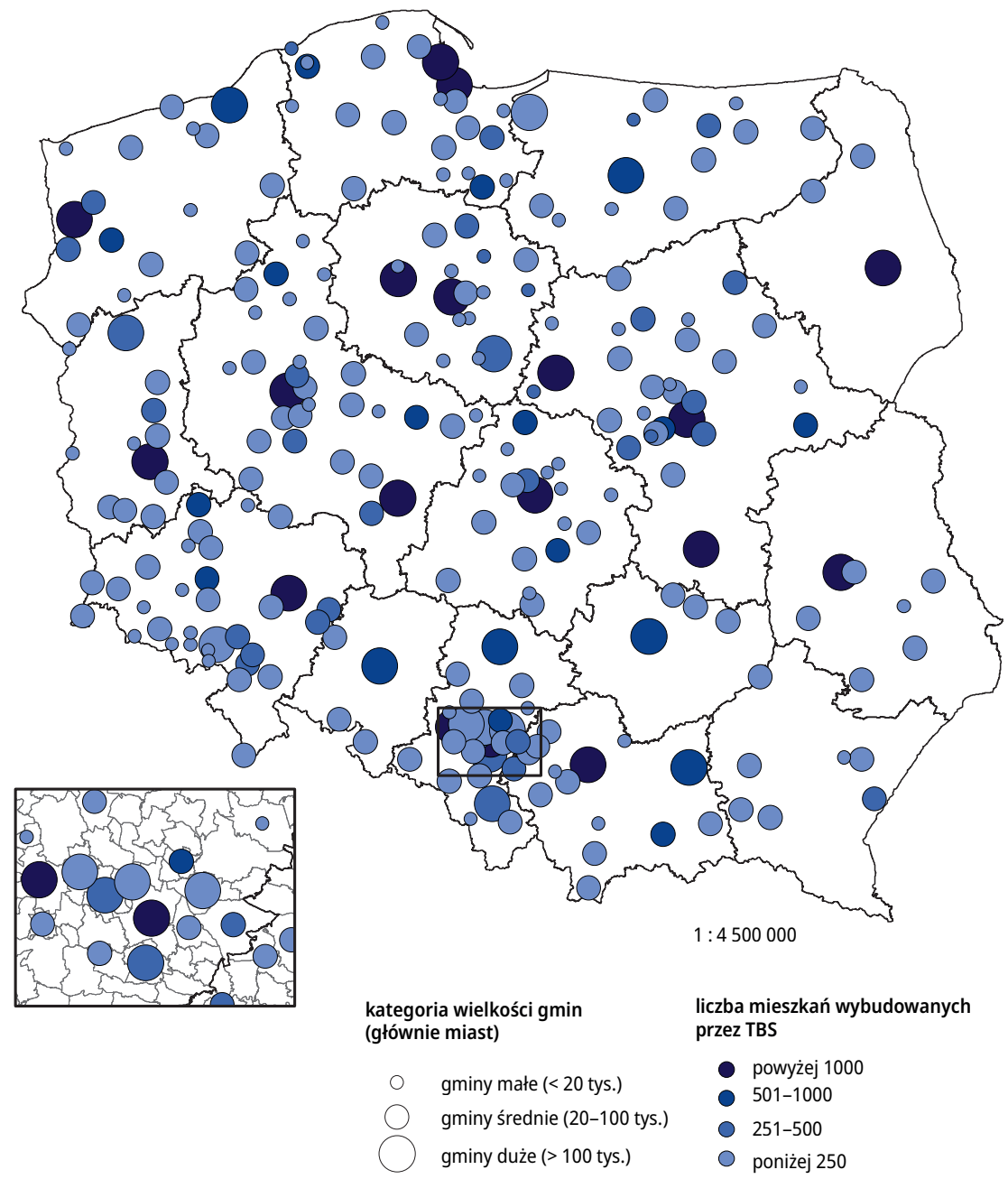

Źródło: opracowanie K. Nowaka na podstawie danych BGK.

tów prywatnych lub z udziałem większościowym) ${ }^{30}$. Społeczne mieszkania czynszowe w formule TBS znajdowały się, według stanu na koniec 2020 r., w 250 miejscowościach, z czego w:

- 72 miejscowościach liczących do 20 tys. mieszkańców,

- 144 miastach średnich, liczących od 20 tys. do 100 tys. mieszkańców,

- 34 miastach dużych, liczących powyżej 100 tys. mieszkańców.

30 Prywatne TBS były aktywne w pierwszych latach funkcjonowania programu, często były powiązane z przedsiębiorstwami budowlanymi. Niemniej nieliczne prywatne towarzystwa nadal realizują nowe inwestycje na podstawie porozumień z gminami, na których terenie działają. 
Zasoby TBS znajdują się we wszystkich największych miastach liczących ponad 200 tys. mieszkańców oraz w większości pozostałych miast dużych i średnich. Wielkość zasobów i aktywność inwestycyjna TBS w poszczególnych miastach są zróżnicowane (rysunek 1). W 56 miastach było zlokalizowanych do 50 mieszkań w formule TBS, w 55 zaś - od 50 do 100 mieszkań. Największe zasoby, powyżej 1000 mieszkań na koniec 2020 r., znajdowały się w Szczecinie (5232) i we Wrocławiu (5039) oraz w Krakowie (4954), Warszawie (3750), Białymstoku (2289), Gdańsku (2717) i Poznaniu (2620). Pomiędzy 1000 a 2000 mieszkań będących w zasobach TBS odnotowano w Bydgoszczy, Gdyni, Lublinie, Łodzi, Płocku, Radomiu, Toruniu i Zielonej Górze. W każdej kategorii wielkościowej miast są bardzo aktywni liderzy, a współpraca TBS z gminą skutkuje stałym zwiększaniem zasobu mieszkań w podstawowej formule oraz tworzeniem zasobów mieszkań czynszowych kierowanych do określonych grup ludności, np. mieszkań wspomaganych dla osób z niepełnosprawnościami lub seniorów, mieszkań na cele rodzinnych domów dziecka, mieszkań dla absolwentów o profilu umiejętności poszukiwanym na lokalnych rynkach pracy. Poza liderami można wyróżnić jeszcze miasta systematycznie, acz w niewielkiej skali tworzące zasoby TBS oraz miasta, które nie kontynuują programu. Te ostatnie pozostają w mniejszości.

Do silnych stron towarzystw budownictwa społecznego zalicza się otwartą formułę organizacyjną, z jednej strony sprzyjającą specjalizacji w budownictwie mieszkaniowym i w zarządzaniu nieruchomościami mieszkaniowymi na wynajem, z drugiej - dającą szerokie możliwości dostosowania profilu działalności do miejscowych wyzwań. Warto wspomnieć o międzygminnych TBS, spółkach, w których udziały ma kilka lub kilkanaście gmin. To formuła pozwalająca na oszczędność kosztów operacyjnych w mniejszych gminach czy gminach w regionach o gęstej sieci miast. Niektóre towarzystwa w odpowiedzi na zainteresowanie przedsięwzięciami z docelową możliwością wykupu wynajmowanego mieszkania występują z propozycją takich rozwiązań. Korzystają z komercyjnego finansowania BGK lub innych banków i partycypacji finansowej przyszłych najemców. Warte podkreślenia jest też zaangażowanie TBS w wielu miastach w programy rewitalizacji. Spółki zajmują się realizacją przedsięwzięć mieszkaniowych na obszarach rewitalizacji polegających na remontach lub zmianie przeznaczenia budynków, a także na nowych budowach uzupełniających struktury urbanistyczne. Wykorzystują do tego celu finansowanie z rządowych programów wspierania mieszkalnictwa, w tym środki Funduszu Termomodernizacji i Remontów, środki z funduszy UE oraz środki własne inwestorów31.

Wsparcie publiczne w formie preferencyjnych kredytów towarzystwa uzyskują w trakcie realizacji inwestycji mieszkaniowej; dalsza eksploatacja zasobów opiera się na zasadach rynkowych. Preferencje kredytowe sprowadzają się do niskiego oprocentowania kredytu (WIBOR 3M), braku marży, wysokiego możliwego udziału kredytu w kosztach przedsięwzięcia i długiego okresu

31 A. Muzioł-Węcławowicz, Funkcje mieszkaniowe w programach rewitalizacji miast [w:] Współczesne uwarunkowania gospodarowania przestrzeniq - szanse i zagrożenia dla zrównoważonego rozwoju, red. A. Maciejewska, Oficyna Wydawnicza Politechniki Warszawskiej, Warszawa 2014, s. 116-129; A. Muzioł-Węcławowicz, Spoteczne budownictwo czynszowe i towarzystwa budownictwa społecznego [w:] Mieszkalnictwo społeczne. Raport o stanie polskich miast, red. A. Muzioł-Węcławowicz, K. Nowak, Instytut Rozwoju Miast i Regionów, Warszawa 2018, s. 178-208. 
spłaty. Towarzystwa ponadto korzystają z przywileju podatkowego - nie płacą podatku dochodowego z tytułu działalności podstawowej, są wspierane finansowo i rzeczowo przez gminy, czyli udziałowców, najczęściej w formie aportu rzeczowego. Miasta - właściciele TBS - w zamian za zwiększanie kapitału TBS oczekują realizacji nowych zasobów dla swoich mieszkańców. Mogą osiągać zyski ze swojej działalności, ale zysk nie może być dzielony między udziałowców i musi być przeznaczony na realizację statutowych celów spółki. Formuła działania TBS pozwala na to, by z przychodów czynszowych było możliwe utrzymanie zasobów w należytym stanie, uwzględniającym bieżące remonty, koszty zarządzania oraz spłatę zobowiązań kredytowych, przy limitowaniu maksymalnej stawki czynszu. Ta nie może przekraczać 4\% lub 5\% wartości odtworzeniowej kosztu budowy $1 \mathrm{~m}^{2}$ powierzchni użytkowej mieszkania w skali roku. W praktyce towarzystwa unikają stosowania najwyższych stawek czynszu z obawy przed zachwianiem terminowości oraz regularności opłat czynszowych i działają efektywnie przy niższych czynszach. Obowiązuje próg dochodów na gospodarstwo domowe zasiedlające po raz pierwszy mieszkanie TBS, będący funkcją przeciętnego wynagrodzenia w województwie i liczby osób w gospodarstwie. Najemcy mieszkań w zasobach TBS mają prawo ubiegać się o dodatki mieszkaniowe, a od początku 2020 r. - także o dopłatę do czynszu w ramach programu Mieszkanie na Start, jeśli zasiedlają nowo oddawane zasoby. Relacje pomiędzy stawką czynszu, spłatą zobowiązań kredytowych, dochodami mieszkańców i kosztami działalności TBS przekładają się na samodzielność finansową spółek w fazie eksploatacji zasobów, przy zachowaniu możliwości finansowania czynszów z dochodów najemców, co pokazano na wykresie 4.

Długoterminowa obserwacja poszczególnych parametrów w Tarnowskim TBS ${ }^{32}$ pokazuje, że stawka czynszu rośnie wolniej niż średnie wynagrodzenie w mieście i minimalne wynagrodzenie w kraju, co potwierdza statystycznie trwałą dostępność mieszkań w zasobach TBS z perspektywy obciążenia dochodów najemców kosztami wynajmu. Według stanu na I kwartał 2021 r. w Tarnowskim TBS obowiązują następujące limity dochodowe:

- dla gospodarstw jednoosobowych minimalny dochód ${ }^{33}$ na poziomie 1750 zł, maksymalny 4327,71 zł (spółka stosuje wyłącznie limit czynszu maksymalnego odpowiadający 4\% wartości odtworzeniowej),

- dla gospodarstw trzyosobowych minimalny dochód na poziomie 3250 zł, maksymalny 8366,80 zł.

Koszt odtworzenia $1 \mathrm{~m}^{2}$ powierzchni mieszkania wynosił w województwie małopolskim (poza Krakowem) w I kwartale 2021 r. 4273 zł $^{34}$, przeciętne wynagrodzenie w Tarnowie w 2019 r. 5217 zł. Tarnowskie TBS dysponowało w I kwartale 2021 r. 678 mieszkaniami czynszowymi wybu-

32 Szczegółowe informacje o warunkach i ofercie najmu mieszkań w zasobach Tarnowskiego TBS sp. z o.o. znajdują się na stronie internetowej towarzystwa: https://www.tarnowskietbs.pl/pl/oferta [dostęp: 7 czerwca 2021 r.].

33 TBS są zobowiązane do stosowania maksymalnego limitu czynszu, część podmiotów przyjmuje także minimalny poziom dochodów.

34 Obwieszczenie Wojewody Małopolskiego z dnia 25 września 2020 r. w sprawie ogłoszenia wysokości wskaźnika przeliczeniowego kosztu odtworzenia $1 \mathrm{~m}^{2}$ powierzchni użytkowej budynków mieszkalnych dla miasta Krakowa oraz województwa małopolskiego, z wyłączeniem miasta Krakowa, na okres 6 miesięcy, od dnia 1 października 2020 r. (Dz. Urz. Woj. Mał., poz. 5993), http://edziennik.malopolska.uw.gov.pl/legalact/2020/5993/. 
Wykres 4. Dynamika zmian stawki czynszu w Tarnowskim TBS sp. z o. o. w porównaniu z inflacją i dynamiką zmian wynagrodzeń w Tarnowie w latach 2001-2021

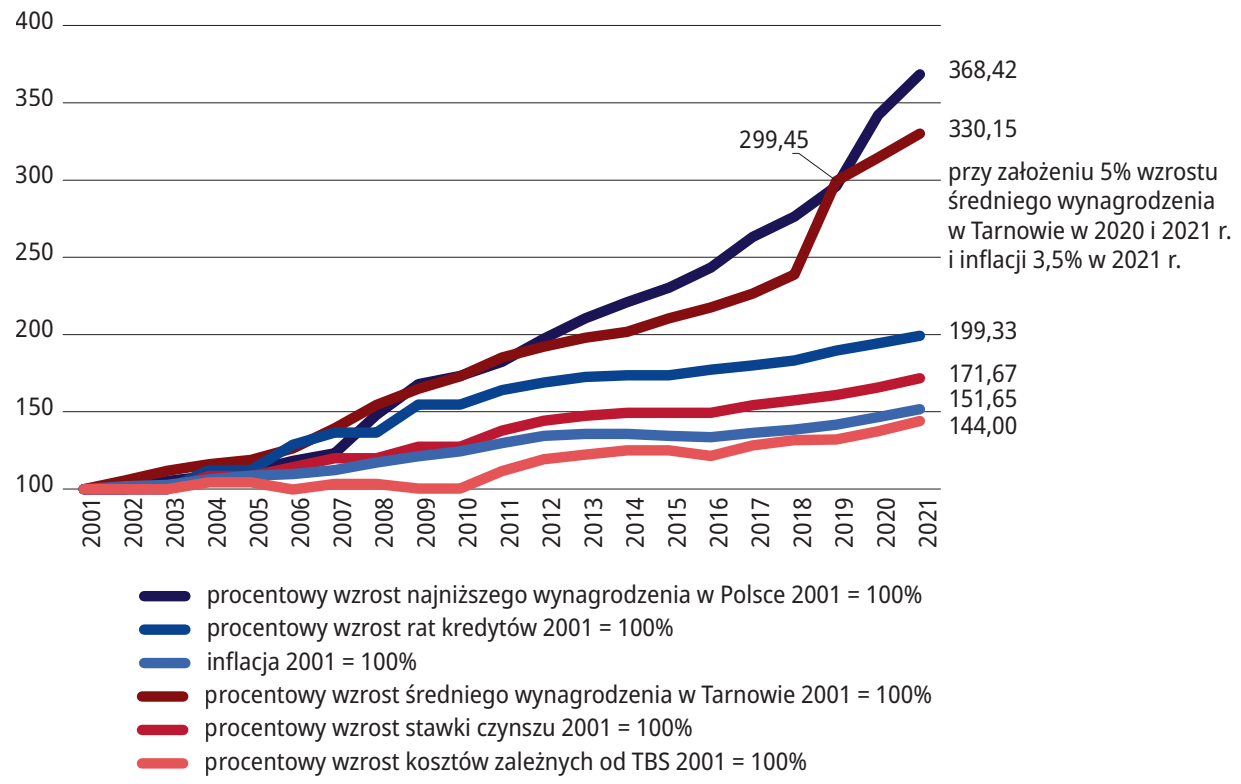

Źródło: opracowanie W. Daniela.

dowanymi z wykorzystaniem preferencyjnego kredytu. Szacuje się, że dodatkowe zapotrzebowanie na mieszkania czynszowe w formule TBS na początku 2021 r. wynosi 600-800 mieszkań, jeśli nie byłaby wymagana partycypacja najemców w kosztach budowy lub byłaby ona bardzo niska, oraz ok. 200 mieszkań z partycypacją poniżej 25\% kosztów budowy ${ }^{35}$.

Do zalet systemu SBC zalicza się również wartość majątku spółek (w większości - majątku komunalnego). Jeśli liczyć tylko nieruchomości wybudowane z wykorzystaniem preferencyjnego kredytu BGK, to 105,3 tys. mieszkań oddanych do użytku do końca 2020 r., o łącznej powierzchni $5,1 \mathrm{mln} \mathrm{m}{ }^{2}$, wartych było $25,8 \mathrm{mld}^{2} \mathfrak{t}^{36}$.

Do barier rozwoju programu społecznego budownictwa czynszowego zalicza się:

- powszechne wymaganie od najemców partycypacji w kosztach budowy,

- presję prywatyzacyjną,

35 Dane Tarnowskiego TBS sp. z o.o.

36 Do wyceny przyjęto cenę $1 \mathrm{~m}^{2}$ powierzchni użytkowej mieszkań oddanych do użytkowania w IV kwartale 2020 r. podaną przez GUS (Komunikat Prezesa Głównego Urzędu Statystycznego z dnia 25 lutego 2020 r. w sprawie ceny $1 \mathrm{~m}^{2}$ powierzchni użytkowej budynku mieszkalnego za IV kwartał 2020 r., https://stat.gov. pl/sygnalne/komunikaty-i-obwieszczenia/lista-komunikatow-i-obwieszczen/komunikat-w-sprawie-ceny-1-m2-powierzchni-uzytkowej-budynku-mieszkalnego-za-iv-kwartal-2020-r-,265,29.html [dostęp: 15 czerwca 2021 r.]); dalej: Komunikat Prezesa GUS. 
- niewystarczające finansowanie lub zaniechanie finansowania programu w latach 2001-2015,

- uzależnienie możliwości inwestycyjnych spółek od politycznych i finansowych decyzji władz gminnych.

Partycypacja osób fizycznych - przyszłych najemców w kosztach budowy może wynieść maksymalnie 30\% kosztów, jest waloryzowana i zwracana, jeśli najemca zrezygnuje z zamieszkiwania lokalu. Tę formę wspomagania budowy inwestycji wprowadzono na początku programu z powodu powszechnego niedoboru środków finansowych na realizację przedsięwzięć mieszkaniowych i ograniczonych możliwości kredytowych w środowisku wysokiej inflacji. Konieczność partycypacji najemców w kosztach budowy jest większą barierą dla potencjalnych lokatorów niż stawki czynszu ${ }^{37}$. Z analiz przeprowadzonych przez R. Cyrana (2019), porównujących koszty początkowe w różnych modelach zaspokajania potrzeb mieszkaniowych w konkretnym mieście, wynika, że dla różnych liczebnie gospodarstw domowych zainteresowanych własnością mieszkania najlepszą opcją jest zakup mieszkania na rynku pierwotnym lub wtórnym ewentualnie wynajem z opcją wykupu mieszkania po 15 latach. Wykup po 30 latach jest nieopłacalny. Dla gospodarstw niezainteresowanych własnością lub szukających tymczasowego mieszkania najbardziej ekonomiczna jest oferta wynajmu mieszkania z TBS, pod warunkiem dostępności tych mieszkań i posiadania środków na partycypację w kosztach. Inne opcje, takie jak najem rynkowy, najem bez opcji wykupu w programie Mieszkanie Plus czy w ramach Funduszu Mieszkań na Wynajem, są droższe. Koszty wejścia do TBS, jeśli jest wymagana partycypacja, są jednak wysokie, gdyż sięgają kilkudziesięciu tysięcy złotych, sam zaś czynsz jest wyraźnie niższy od obowiązującego w innych wymienionych modelach.

Praktyka partycypacji w kosztach ma także dodatkowy negatywny efekt w postaci postrzegania partycypacji jako formy wkładu własnego w realizację inwestycji, dającej nadzieję na uzyskanie odrębnej własności. Takie oczekiwanie nie znajduje podstaw w systemie, ale w wyniku presji prywatyzacyjnej kilkakrotnie zmieniano przepisy w tym zakresie. Partycypacja najemców w kosztach budowy jest jednak potrzebna ze względu na niewystarczające finansowanie programu ze środków rządowych. I choć wola właściciela spółki w kwestii skali i obszarów aktywności w budownictwie mieszkaniowym jest różna w różnych miastach - przeważa systematyczne zlecanie inwestycji czynszowych - interesujące byłoby sprawdzenie, w jakim stopniu na decyzje władz samorządowych o rozwijaniu inwestycji TBS wpływa z jednej strony zmienność programów polityki państwa, a z drugiej - skłonność do nadmiernie optymistycznego przekazu dotyczącego nowych rozwiązań. Te nowe obiecujące zapowiedzi skupiają uwagę i mogą wpływać na zaniechanie lub opóźnienie realizacji wcześniejszych założeń.

37 R. Cyran, Wpływ podmiotowych instrumentów polityki mieszkaniowej na koszty utrzymania mieszkania i model zaspokajania potrzeb [w:] Mieszkalnictwo w Polsce. Przyszłość najmu społecznego, red. A. Muzioł-Węcławowicz, Habitat for Humanity Poland, Warszawa 2019, s. 171-207, https://habitat.pl/wp-content/uploads/2019/04/ Mieszkalnictwo-w-Polsce-Przyszlosc-najmu-spolecznego.pdf [dostęp: 15 czerwca 2021 r.]; A. Muzioł-Węcławowicz, Społeczne budownictwo czynszowe..., s. 178-208. 


\section{Zapotrzebowanie na społeczne mieszkania czynszowe}

Wśród pomysłów na poprawę stanu mieszkalnictwa w Polsce pojawia się postulat gromadzenia rzetelnych i szczegółowych informacji o podaży mieszkań i popycie na nie w ujęciu uwydatniającym sektory mieszkaniowe, układy przestrzenne (w tym wewnątrzmiejskie), grupy społeczne i dochodowe ludności, z wyróżnieniem tych osób, które nie mogą zaspokajać potrzeb mieszkaniowych na rynku. Szacunkowa wielkość deficytu mieszkaniowego waha się od 641 tys. ${ }^{38}$ do 2,1 $\mathrm{mln}^{39}$ lokali mieszkalnych. Zdarzają się też opinie, że nie ma w Polsce deficytu mieszkaniowego, oparte na porównaniu liczby mieszkań i gospodarstw domowych, sumowaniu wielkości zasobów w budowie i/lub prognoz depopulacyjnych. Niektóre informacje traktowane są jako pewne, mimo że nie są poparte systematycznymi badaniami. Tak jest w przypadku tezy o przywiązaniu Polaków do własności mieszkaniowej, opinii, że 40-60\% gospodarstw domowych nie jest w stanie zaspokoić swoich potrzeb mieszkaniowych na rynku oraz że zawsze prywatny rynek najmu oferuje bardzo wysokie stawki czynszu. Szczególnych trudności przysparza ocena zapotrzebowania na społeczne mieszkania czynszowe. Wynika to z braku informacji o dochodach gospodarstw domowych, w tym gospodarstw o niezaspokojonych potrzebach mieszkaniowych. Szacunki liczby gospodarstw potrzebujących mieszkań nie odzwierciedlają faktycznych potrzeb gospodarstw domowych, które nie mają dostępu do samodzielnie zajmowanego mieszkania lub mieszkają w nieodpowiednich, niezdrowych warunkach, w przeludnieniu.

Trudno o wspartą badaniami ilościowymi i jakościowymi diagnozę liczby potrzebnych mieszkań komunalnych. Odnosimy się do liczby gospodarstw domowych oczekujących na najem mieszkania komunalnego, która w 2018 r. wyniosła 149,3 tys., a w 2019 r. - 150,6 tys. Tę liczbę uznaje się za minimalną wielkość zapotrzebowania. Największe kolejki po mieszkania komunalne są w województwach: śląskim (33,2 tys. mieszkań), dolnośląskim (16,3 tys.) i mazowieckim (14,2 tys.), najmniejsze zapotrzebowanie odnotowano w województwach: lubelskim (0,6 tys.), podlaskim i podkarpackim (po 0,5 tys.). Komunalna gospodarka mieszkaniowa traci rocznie więcej mieszkań, niż ich buduje, w wyniku zwrotu nieruchomości właścicielom, a przede wszystkim z powodu sprzedaży lokali najemcom. W 2018 r. najemcy kupili 34,8 tys. mieszkań komunalnych, właściciele odzyskali 0,7 tys., a wybudowano zaledwie 1,9 tys. W ostatnim dziesięcioleciu notuje się jednak spadek liczby mieszkań sprzedawanych - miasta rezygnują albo w ogóle ze sprzedaży mieszkań komunalnych, albo ze stosowania wysokiej bonifikaty przy transakcjach. Polityka odsprzedawania mieszkań komunalnych jest sprzeczna z potrzebami społecznymi, a szerszej dyskusji wymaga strona ekonomiczna tego rozwiązania. Dodatkowo dostępność mieszkań komunalnych ograniczają pustostany komunalne (54,2 tys. w 2018 r.). Niewielką część potrzeb mieszkaniowych można zaspokoić w drodze rotacji najemców. Kryteria dochodowe uprawniające do najmu socjalnego i najmu standardowego w zasobach komunalnych są ustalane lokalnie, na podstawie dość zróżnicowanych wymogów. Nie ma więc pewności, że osoby o dochodach nieznacznie przewyższających lokalne progi mogą

38 Ministerstwo Rozwoju, Raport. Stan mieszkalnictwa w Polsce, Warszawa 2020.

39 Indeks HRE. Indeks koniunktury na rynku mieszkaniowym w IV kwartale 2020 r., HRE Think Tank, Warszawa 2021. 
skorzystać z innych możliwości uzyskania mieszkania. Z perspektywy państwa jest ważne, jaka wysokość dochodów w relacji do kosztów utrzymania zostanie uznana za referencyjną dla systemu mieszkalnictwa komunalnego, obsługującego społeczności najsłabsze dochodowo i/lub wykluczone społecznie bądź zagrożone takim wykluczeniem. Usługi mieszkaniowe są bodajże najdroższymi jednostkowo usługami publicznymi, co stawia gminy przed trudnymi decyzjami. Szerokich analiz w skali państwa, regionalnej i lokalnej wymagają też kontekst demograficzny i prognozowane zmiany liczby ludności, uwzględniające migracje wewnętrzne i zewnętrzne.

Jeszcze trudniej o ocenę efektywnego zapotrzebowania na mieszkania w systemie TBS w podstawowej formule - wynajmu mieszkań osobom o średnich dochodach. Towarzystwa nie prowadzą rejestracji chętnych do wynajęcia mieszkań. Ogłaszają jedynie bieżącą ofertę najmu zwalnianych mieszkań, a nabór do zasiedlenia nowych ogłaszają po uzyskaniu gwarancji finansowania i rozpoczęciu budowy. Nie ma pustostanów w zasobach TBS, ale w części mniejszych miejscowości - według opinii przedstawicieli TBS - występuje niewielki popyt na mieszkania, których najem wiąże się z wysoką partycypacją w kosztach budowy. Dane historyczne wskazują, że potencjał towarzystw budownictwa społecznego pozwala na realizację 10 tys. mieszkań rocznie. W latach 2000-2005, mimo niemożności realizacji wszystkich projektów inwestycyjnych, towarzystwa oddawały od 7,1 tys. do 9,9 tys. mieszkań rocznie (najwięcej w 2003 r.). Taka jest więc także liczba najemców mieszkań TBS, których stać na partycypację w kosztach inwestycji. Znaczące ograniczenie partycypacji mogłoby doprowadzić do znacznego zwiększenia zapotrzebowania na społeczne mieszkania czynszowe.

Jeśli chodzi o kapitał potrzebny do budowy społecznych mieszkań czynszowych, to największymi kredytobiorcami są towarzystwa z największych miast. W dziewięciu edycjach naboru wniosków kredytowych w nowej formule kredytowania przez BGK wnioski na budowę lub kapitalny remont napłynęły głównie z Warszawy (1402 mieszkania), z Wrocławia (1272), ze Szczecina (946), z tego oddano już do użytku (stan na koniec 2020 r.) odpowiednio: 141, 429 i 279 mieszkań ${ }^{40}$. Bank od 2015 r. do końca 2020 r. przyjął do realizacji zweryfikowane pod kątem wiarygodności kredytowej 273 wnioski złożone w związku z planowaną budową mieszkań na terenie 129 miejscowości. Z tego w 28 miastach, m.in.: Dzierżoniów, Głogów, Gryfice, Jarocin, Jaworzno, Jelcz-Laskowice, Krosno, Pszczyna, Pruszków, Świdnica, Wyszków i Zakopane, zostało lub zostanie wybudowanych powyżej 100 mieszkań. Należy podkreślić, że kredytobiorcami są też spółdzielnie mieszkaniowe realizujące mieszkania lokatorskie i spółki komunalne niebędące TBS. Spółdzielcze realizacje są finansowane w 10 miastach, o kredyt wnioskowały spółki komunalne niebędące TBS z Gniewu, Karczewa, Otwocka, Poznania, Rokietnicy, Sejn, ze Świnoujścia, z Turku i Wałbrzycha. Rozszerzenie dostępu do preferencyjnego finansowania dla spółek komunalnych i spółdzielni mieszkaniowych należy uznać za korzystne rozwiązanie.

40 Szczególna sytuacja zaistniała w Poznaniu; Poznańskie TBS korzystało od 2018 r. z bezpośredniej linii kredytowej Europejskiego Banku Inwestycyjnego (EBI) przy realizacji programu budowy ok. 1000 mieszkań czynszowych. Obecnie spółka korzysta z kredytów EBI i BGK. 
Partycypacja w kosztach budowy stanowi zasadniczą barierę dostępności zasobów TBS. Wydaje się, że tę przeszkodę można pokonać dzięki zwiększeniu wsparcia rządowego w formie grantów dla gmin zlecających towarzystwom budowę mieszkań czynszowych. TBS już ograniczają maksymalną partycypację, by uniknąć w przyszłości roszczeń prywatyzacyjnych ${ }^{41}$.

Polityka społeczna państwa związana ze wsparciem gospodarstw domowych z dziećmi i emerytów oraz dobra koniunktura gospodarcza w kraju dały błędny sygnał, że gospodarstwa domowe, mające dotychczas niższe dochody, uzyskały zdolność finansową na rynku nieruchomości ${ }^{42}$. Do podobnych wniosków skłaniają dane z badań budżetów gospodarstw domowych. Średnio wydatki gospodarstw domowych na użytkowanie mieszkania i nośniki energii na jedną osobę wyniosły w 2019 r. 18\% ogółu wydatków, w I grupie kwintylowej - 18,3\%, w kolejnych odpowiednio: 19,6\%, 19,2\%, 16\%, 16,6\% ${ }^{43}$. To wskazuje na dużą statystyczną rezerwę względem progu 30\% wydatków budżetów domowych uznawanych w międzynarodowych badaniach porównawczych za poziom bezpieczny, pozwalający na zaspokojenie innych podstawowych potrzeb. Nie dysponujemy jednak danymi o budżetach gospodarstw nieużytkujących samodzielnego mieszkania czy wynajmujących mieszkania na rynku. Można się jedynie domyślać, jakie są obciążenia czynszowe osób z niższych grup dochodowych w zależności od rodzaju zajmowanego zasobu i stawki czynszu. Gdy przyjmiemy, że stawki czynszu w poszczególnych rodzajach zasobu wynoszą ${ }^{44}$ :

- 8-12\% wartości odtworzeniowej na rynku i w zasobach Funduszu Mieszkań na Wynajem,

- 4-5\% wartości odtworzeniowej w zasobach towarzystw budownictwa społecznego,

- 1-3\% wartości odtworzeniowej w zasobach komunalnych,

- 7-11\% wartości odtworzeniowej w zasobach programu Mieszkanie Plus z opcją wykupu mieszkania,

- $5 \%$ wartości odtworzeniowej w zasobach programu Mieszkanie Plus bez opcji wykupu mieszkania,

możemy pokazać bariery dostępności czynszowej mieszkań (tabela 1). Przy tworzeniu zestawienia przyjęto wysoce ogólne założenia - wykorzystano informacje o budżetach domowych uporządkowanych według wysokości wydatków oraz o koszcie budowy $1 \mathrm{~m}^{2}$ mieszkania w IV kwartale 2019 r. określonym przez GUS ${ }^{45}$. Takie ujęcie ma jedynie orientacyjny charakter. Przy założeniu, że wydatki na czynsz, niebędący zresztą jedynym elementem kosztów użytkowania mieszkania, nie powinny przekraczać 30\% budżetu gospodarstwa, dla gospodarstw dwuosobowych z I kwintyla dochodowego jedynym dostępnym mieszkaniem jest to z czynszem

41 Na podstawie ustawy z dnia 10 grudnia 2020 r. o zmianie niektórych ustaw wspierających rozwój mieszkalnictwa najemcy, którzy wpłacili partycypację w wysokości co najmniej 25\% kosztów budowy lokalu w miastach wojewódzkich i na prawach powiatu liczących co najmniej 100 tys. mieszkańców oraz 20\% w pozostałych miejscowościach, mają prawo ubiegać się - po spłacie kredytu przez towarzystwo - o rozliczenie partycypacji jako części środków na wykup tego mieszkania.

42 P. Jarecki, E. Kucharska-Stasiak, A. Miklaszewska, K. Olbińska, B. Wieteska-Rosiak, M. Załężna, op. cit., s. 62.

43 Główny Urząd Statystyczny, Budżety gospodarstw domowych w 2019 roku, Warszawa 2020.

44 R. Cyran, op. cit.

45 Komunikat Prezesa GUS. 
komunalnym na poziomie $1 \%$ wartości odtworzeniowej ${ }^{46}$, dla gospodarstw z II i III kwintyla również to z czynszem komunalnym w wysokości 3\% wartości odtworzeniowej. W III kwintylu dostępne są też stawki niższe niż 4\% wartości odtworzeniowej, obowiązujące w TBS. Dla trzyosobowych gospodarstw osiągalny jest najem komunalny i najem lokali z zasobów towarzystw budownictwa społecznego z niższą stawką maksymalną. Pozostałe zasoby czynszowe - prywatne, Funduszu Mieszkań na Wynajem, programu Mieszkanie Plus - są niedostępne co najmniej dla trzech pierwszych kwintyli dochodowych, czyli dla $60 \%$ gospodarstw domowych. A mowa tu o mieszkaniu o powierzchni $45 \mathrm{~m}^{2}$.

Tabela 1. Udział stawek czynszu w wydatkach gospodarstw domowych z I-III kwintyla dochodowego w 2019 r.

\begin{tabular}{|c|c|c|c|c|c|c|c|}
\hline \multirow{3}{*}{ 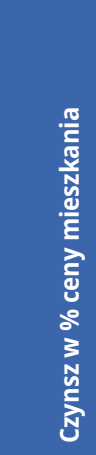 } & \multirow{3}{*}{ 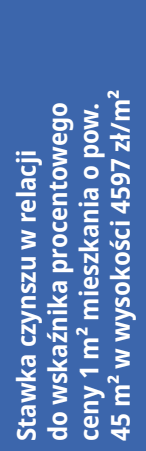 } & 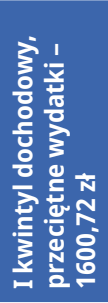 & 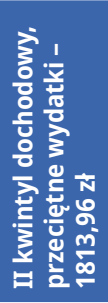 & 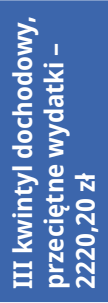 & 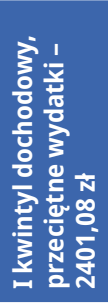 & 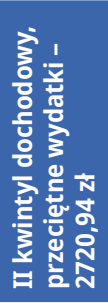 & 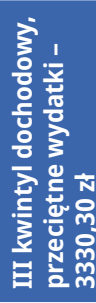 \\
\hline & & \multicolumn{6}{|c|}{ Udział czynszu w wydatkach gospodarstwa domowego (w \%) } \\
\hline & & \multicolumn{3}{|c|}{$\begin{array}{c}\text { Dwuosobowe gospodarstwo } \\
\text { domowe }\end{array}$} & \multicolumn{3}{|c|}{$\begin{array}{c}\text { Trzyosobowe gospodarstwo } \\
\text { domowe }\end{array}$} \\
\hline $1 \%$ & 172,39 & 10,77 & 9,50 & 7,76 & 7,18 & 6,34 & 5,18 \\
\hline $3 \%$ & 517,17 & 32,31 & 28,51 & 23,29 & 21,54 & 19,01 & 15,53 \\
\hline $4 \%$ & 689,56 & 43,08 & 38,01 & 31,06 & 28,72 & 25,34 & 20,71 \\
\hline $5 \%$ & 861,95 & 53,85 & 47,52 & 38,82 & 35,90 & 31,68 & 25,88 \\
\hline $7 \%$ & 1206,73 & 75,39 & 66,52 & 54,35 & 50,26 & 44,35 & 36,23 \\
\hline $11 \%$ & 1896,26 & 118,46 & 104,54 & 86,19 & 78,98 & 69,69 & 56,94 \\
\hline $12 \%$ & 2068,68 & 129,23 & 114,04 & 93,18 & 86,16 & 76,03 & 62,12 \\
\hline
\end{tabular}

Źródło: obliczenia własne na podstawie publikacji Głównego Urzędu Statystycznego, Budżety gospodarstw domowych w 2019 roku.

Powyższe konstatacje nie dają odpowiedzi na pytanie, ile potrzebujemy dodatkowych mieszkań czynszowych, ale potwierdzają tezę o potrzebie rozwoju sektora mieszkań komunalnych i w zasobach TBS jako nieobciążających nadmiernie budżetów gospodarstw domowych.

46 To kolejne uproszczenie, do obliczeń przyjęto ogólnopolski wskaźnik kosztu budowy, a nie regionalnie przeliczaną wartość odtworzeniową kosztu budowy $1 \mathrm{~m}^{2}$ powierzchni użytkowej mieszkań. 


\section{Nowe regulacje prawne}

W mieszkalnictwie społecznym wprowadzono wiele zmian prawnych mających zwiększyć efekty budownictwa i dostępność mieszkań. Znaczące wsparcie finansowe otrzymują gminy realizujące mieszkania komunalne i budowane przez TBS w klasycznej formule lub na wynajem na zasadach komunalnych. Ustawowo ${ }^{47}$ podniesiono, w większości przypadków, do 80\% kosztów budowy udział dofinansowania ze środków Funduszu Dopłat. Powołano też Rządowy Fundusz Rozwoju Mieszkalnictwa, z którego gminy mogą otrzymać dodatkowe dotacje na mieszkalnictwo społeczne. Rozszerzono pole aktywności Krajowego Zasobu Nieruchomości, który stał się partnerem gmin w tworzeniu TBS. KZN wnosi aport rzeczowy w formie gruntów budowlanych ze swojego zasobu i tworzy spółkę z gminami.

Zmiany dotyczące regulacji społecznego budownictwa czynszowego wprowadzone ustawą z dnia 10 grudnia 2020 r. o zmianie niektórych ustaw wspierających rozwój mieszkalnictwa są przedmiotem szczegółowych dyskusji. Większości postulatów środowisk samorządowych i stowarzyszeń reprezentujących TBS nie uwzględniono w procesie konsultacji społecznych ani tym bardziej w procesie legislacyjnym. Środowiska te bardzo dobrze przyjęły propozycje zmian w finansowaniu, ale opinie o pozostałych rozwiązaniach planowanych przez rząd często były krytyczne. Do najbardziej dyskusyjnych kwestii zalicza się:

- wprowadzenie rozwiązań pozwalających na rozliczenie partycypacji w trakcie najmu mieszkania po spłacie przez inwestora zobowiązań kredytowych w formie częściowych wakacji czynszowych,

- wprowadzenie rozwiązań pozwalających na przekształcenie lokali w mieszkania własnościowe przez rozliczenie partycypacji po spłacie przez inwestora zobowiązań kredytowych i po przejściu na formułę najmu okazjonalnego z dojściem do własności,

- wprowadzenie możliwości przeniesienia na najemcę, który wniósł partycypację, za zgodą właścicieli spółki własności lokalu po upływie 5 lat od daty wydania pozwolenia na użytkowanie budynku,

- znaczące obniżenie progów dochodowych (od 1 lipca 2021 r.) dla osób ubiegających się o najem mieszkań wybudowanych przez TBS z wykorzystaniem instrumentów wsparcia gmin określonych w ustawie ${ }^{48}$.

47 Ustawa z dnia 10 grudnia 2020 r. o zmianie niektórych ustaw wspierających rozwój mieszkalnictwa (Dz.U. 2021, poz. 11).

48 Za dość dziwną i niepotrzebną uznaje się zmianę terminologii określającej inwestorów społecznego budownictwa czynszowego. Dotychczasowe towarzystwa budownictwa społecznego (TBS) przekształca się w „nowym otwarciu rządowym" w społeczne inicjatywy mieszkaniowe (SIM). Nie zmieniono przy tym ani jednej normy dotyczącej zakresu, przedmiotu czy formy działania towarzystw. Projektodawca arbitralnie uznał, że "społeczna inicjatywa mieszkaniowa” jest „określeniem bardziej oddającym charakter tych podmiotów" (uzasadnienie rządowego projektu ustawy o zmianie niektórych ustaw wspierających rozwój mieszkalnictwa, Sejm IX kadencji, druk nr 534, https://www.sejm.gov.pl/sejm9.nsf/druk.xsp?nr=534 [dostęp: 24.04 .2021 r.]), przy czym nie powołał się na żadne analizy lingwistyczne czy prawne ani na inspiracje czy sugestie ze strony podmiotów zaangażowanych w proces inwestycyjny. Mamy w efekcie chaos informacyjny i wzrost biurokracji. 
Wprowadzono nowe rozwiązania: program Lokal za Grunt ${ }^{49}$ oraz Grant na Infrastrukturę ${ }^{50}$. W pierwszym z nich chodzi o umożliwienie gminom oddania inwestorom gruntów budowlanych w zamian za przekazanie gminie lokali mieszkalnych lub użytkowych jako częściowe rozliczenie ceny nieruchomości nabytej przetargowo. W drugim programie przewidziano dofinansowanie w wysokości 10\% kosztów infrastruktury społecznej lub technicznej towarzyszącej mieszkalnictwu. Zapowiadane są dalsze inicjatywy legislacyjne mające na celu wdrożenie społecznych agencji najmu, kooperatyw mieszkaniowych, usprawnienie działalności spółdzielczości mieszkaniowej i wspólnot mieszkaniowych. Zmiany dotkną także otoczenia mieszkalnictwa - Prawa budowlanego i wielokrotnie zapowiadanej reformy planowania przestrzennego.

W kontekście wcześniejszych regulacji prawnych w mieszkalnictwie zwraca uwagę tendencja do fragmentaryzacji i rozdrobnienia przyjmowanych rozwiązań, wynikająca z partykularnych potrzeb wspierania programów wprowadzanych przez rząd. Efekty tych zmian są niewielkie, dodatkowo oddalają systemowe reformy sektora mieszkaniowego. Mowa tu m.in. o najmie okazjonalnym i instytucjonalnym, skróceniu i uproszczeniu (nawet wbrew zapisom planów miejscowych) procedur decyzyjnych w kwestii zgody na budowę, o powrocie do opcji prywatyzacji zasobów TBS, wprowadzeniu dopłat do czynszów (Mieszkanie na Start) wyłącznie dla zajmujących nowo budowane lokale na wynajem. Pozytywne efekty tych rozwiązań są niewielkie. Najem instytucjonalny chroni inwestora (w tym Fundusz Mieszkań na Wynajem, PFR Nieruchomości) przed utrudnieniami eksmisyjnymi w przypadku najemców zalegających z opłatą czynszu. Gminy miejskie opracowują lokalne standardy urbanistyczne, by ograniczyć skutki „lex deweloper"51. Blokowana jest systemowa reforma dodatków mieszkaniowych, w zamian za pomocą środków budżetowych promuje się wyłącznie nowe budownictwo czynszowe ${ }^{52}$. Dopłaty do czynszów wzmacniają głównie rynkowych inwestorów czynszowych - Fundusz Mieszkań na Wynajem, PFR Nieruchomości, ale także TBS. Do końca 2020 r. żaden całkowicie prywatny inwestor nie skorzystał z możliwości dopłat. Opcja prywatyzacji mieszkań TBS na rzecz najemców po raz kolejny jest wyłomem w zasadzie, że priorytetem powinno być tworzenie trwałego społecznego zasobu czynszowego. Dla konkretnego najemcy perspektywa przeniesienia własności zajmowanego lokalu po spłacie kredytu przez TBS, czyli 30 lat od chwili zasiedlenia, nie jest optymalnym rozwiązaniem. W tym czasie będą się zmieniały jego potrzeby, stosownie do fazy życia rodzinnego czy miejsca pracy, a także preferencje lokalizacyjne. W przypadku jednak poprawy sytuacji dochodowej i potrzeby posiadania własności użytkowanego mieszkania najemca TBS może w każdej chwili zrezygnować z najmu i przeznaczyć zwaloryzowaną kwotę partycypacji na kupno mieszkania na rynku. Lokale z zasobów TBS mają być bowiem sprze-

49 Ustawa z dnia 16 grudnia 2020 r. o rozliczaniu ceny lokali lub budynków w cenie nieruchomości zbywanych z gminnego zasobu nieruchomości (Dz.U. 2021, poz. 223).

50 Program dodano do zadań Funduszu Dopłat na podstawie noweli ustawy z 8 grudnia 2006 r. o finansowym wsparciu tworzenia lokali mieszkalnych na wynajem, mieszkań chronionych, noclegowni, schronisk dla osób bezdomnych, ogrzewalni i tymczasowych pomieszczeń (Dz.U. 2021, poz. 223).

51 Ustawa z dnia 22 sierpnia 2018 r. o ułatwieniach w przygotowaniu i realizacji inwestycji mieszkaniowych oraz inwestycji towarzyszących (Dz.U. 2020, poz. 219, ze zm.).

52 Formalnie z programu Mieszkanie na Start mogą korzystać również najemcy mieszkań remontowanych, ale wyłącznie na obszarach specjalnych stref rewitalizacji. 
dawane po cenie rynkowej, zatem najemcy nie skorzystają z preferencji podobnych do tych, jakie stosowano przy prywatyzacji mieszkań komunalnych. Do tego dochodzi ryzyko kolejnych zmian przepisów. Właściwszą formą zmiany mieszkania, dającą więcej możliwości pozyskania mieszkania odpowiadającego potrzebom i możliwościom finansowym, jest przejście, na indywidualnych warunkach, do innego sektora z wykorzystaniem kapitału pochodzącego ze zwrotu partycypacji.

Szczegółowa analiza regulacji prawnych w mieszkalnictwie i poszukiwanie drogi systemowego porządkowania i upraszczania przepisów powinny być przedmiotem odrębnych studiów. Pozytywnie ocenia się gotowość państwa do znacznego zwiększenia finansowego zaangażowania budżetu państwa w rozwój mieszkalnictwa dostępnego gmin i ich spółek oraz wielość form wspierania rozwoju budownictwa mieszkaniowego, od rozwiązań silnie subsydiowanych po działania zbliżone do zasad rynkowych.

\section{Podsumowanie}

Krytycznym czynnikiem warunkującym sukces mieszkalnictwa społecznego będzie zapewnienie przez państwo środków finansowych potrzebnych gminom i innym podmiotom, głównie TBS, do rozwoju sektora społecznych mieszkań czynszowych. Wysokość środków finansowania zwrotnego, które BGK ma przeznaczyć na kredyty w ramach naboru wniosków w marcu 2021 r., to 1,6 mld zł, ale średniorocznie w latach 2015-2024 ma to być 0,4 mld zł. Wzrost aktywności TBS może w krótkim czasie zmniejszyć oszczędności w budżecie programu z lat wcześniejszych. BGK poinformował, że w 2021 r. w wiosennym naborze projektów do preferencyjnego kredytowania, na nowych warunkach, wpłynęło wyjątkowo dużo wniosków, niemal wyłącznie od TBS ${ }^{53}$. Przyjęto wnioski na łączną kwotę prawie $700 \mathrm{mln}$ zł, o ponad 20\% więcej niż jesienią $2020 \mathrm{r}$. Może powstać w sumie ok. 4,3 tys. mieszkań, a koszt planowanych przedsięwzięć wynosi 1,3 mld zł. Roczne zapotrzebowanie na kredyty pozwalające na budowę 10 tys. mieszkań w formule SBC w cenach z edycji wiosennej 2021 r. szacuje się na ok. 1,6 mld zł.

W ustawie budżetowej na 2021 r. środki Funduszu Dopłat na wsparcie realizacji mieszkań czynszowych i program dopłat do czynszu określono na 300 mln zł ${ }^{54}$. W latach 2021-2025 na pokrycie części kosztów dofinansowania budowy mieszkań komunalnych oraz na wynajem przewiduje się rocznie maksymalnie $1 \mathrm{mld} z ł^{55}$. Zwiększenie poziomu wsparcia z 20-55\% do 80\% kosztów głównych przedsięwzięć wspieranych środkami FD nie rokuje sfinansowania z budżetu zwiększonego zapotrzebowania wszystkich gmin po 2021 r. Z informacji ministerialnych wynika, że samo miasto Kraków wnioskuje w 2021 r. do FD o dotację wynoszącą ok. 120 mln zł na budowę

53 https://www.portalsamorzadowy.pl/gospodarka-komunalna/coraz-wiecej-mieszkan-dla-sredniozamoznych-1-lipca-ruszy-kolejna-edycja-waznego-programu,275507.html [dostęp: 7 maja 2021 r.].

54 Załącznik nr 2 do ustawy budżetowej na rok 2021 z dnia 20 stycznia 2021 r. (Dz.U. 2021, poz. 190), cz. 83 Rezerwa celowa, poz. 61.

55 https://www.gov.pl/web/rozwoj-praca-technologia/wsparcie-inwestorow-w-tym-gmin-w-obszarze-budownictwa-komunalnego-i-spolecznego [dostęp: 7 czerwca 2021 r.]. 
ok. 650 mieszkań komunalnych ${ }^{56}$, a to jedna trzecia obecnego budżetu programu. W 2019 r. Bank Gospodarstwa Krajowego sfinansował ze środków Funduszu Dopłat 18 przedsięwzięć realizowanych przez TBS na zamówienie gmin, z 1072 mieszkaniami. Wartość tych inwestycji wyniosła 251,6 mln zł, a samo dofinansowanie - 64,3 mln zł. Grant w wysokości 80\% kosztów budowy wymagałby dla tych realizacji ok. $201 \mathrm{mln}$ zł.

Nie powinno być problemów z finansowaniem zapotrzebowania zgłaszanego przez gminy i TBS w 2021 r. Nowe przepisy weszły w życie od 19 stycznia 2021 r., a przygotowanie projektów inwestycyjnych będzie wymagać czasu. Nie oczekuje się zatem lawinowego wzrostu zapotrzebowania na preferencyjne finansowanie zwrotne TBS oraz na dotacje dla gmin z FD już w 2021 r.

Zakładana w NPM likwidacja kolejki po mieszkania komunalne powinna skutkować, w najprostszym szacunku, wobec aktualnego minimalnego zapotrzebowania rzędu 150,6 tys. mieszkań, budową 15,1 tys. mieszkań komunalnych rocznie do 2030 r. Jeśli przyjmiemy wartość przedsięwzięć na poziomie społecznego budownictwa czynszowego z 2020 r., to roczny koszt inwestycji dla gmin wyniósłby ok. 4,3 mld zł, a dotacja w wysokości 80\% kosztów - 3,4 mld zł w ciągu roku. W opinii autorki, aby rozwiązać problem zapotrzebowania na mieszkania czynszowe o dostępnym czynszu, realne wsparcie budżetowe mieszkalnictwa społecznego w Polsce w najbliższych latach powinno pozwolić na budowę po ok. 10 tys. komunalnych mieszkań na wynajem oraz ok. 10 tys. w zasobach TBS. To nadal byłby udział na poziomie ok. $10 \%$ ogółu budowanych mieszkań.

Drugim warunkiem znaczącego rozwoju mieszkalnictwa społecznego jest dobra sytuacja budżetowa miast. Efekty pandemii COVID-19 i reform podatkowych są w tym zakresie czynnikami mogącymi negatywnie wpłynąć na zdolność gmin do wykorzystania zwiększonego wsparcia budżetowego.

Ze względu na ograniczenia objętościowe artykułu w pracy nie podjęto wszystkich wątków mieszkalnictwa społecznego. Pominięto istotne zagadnienia substandardu mieszkaniowego w mieszkaniowych zasobach gmin, powodujące zagrożenia środowiska i zdrowia mieszkańców oraz dyskomfort mieszkaniowy. W istniejących zasobach tkwi duży potencjał mieszkaniowy i urbanistyczny. Ich odnowa, szczególnie koordynowana w ramach rewitalizacji, ma duże znaczenie dla jakości życia użytkowników zasobów, dla ochrony środowiska, ładu i estetyki otoczenia. Postulat miasta zwartego wymaga skupienia inwestycji mieszkaniowych na obszarach zurbanizowanych, dobrze połączonych komunikacją publiczną i wyposażonych w infrastrukturę społeczną. Postuluje się opracowanie i wdrożenie rządowego programu wieloletniego wspierania remontów i modernizacji publicznych zasobów mieszkaniowych. Projekt Długoterminowej Strategii Renowacji z lutego 2021 r. ma charakter diagnostyczny i przedstawia wytyczne w dziedzinie energii i klimatu. Termomodernizacja powinna stanowić podstawę odnowy zasobów mieszkaniowych, ale dla poprawy standardu i komfortu są konieczne także inne działania remontowe i modernizacyjne.

Pominięto też sprawy podmiotowych instrumentów służących zwiększaniu dostępności mieszkań czynszowych. Należy podjąć szerokie prace nad ewaluacją systemu dodatków

56 https://www.gov.pl/web/rozwoj-praca-technologia/rzad-dofinansuje-budownictwo-komunalne-w-krakowie [dostęp: 7 czerwca 2021 r.]. 
mieszkaniowych i dopłat do czynszów z programu Mieszkanie na Start. W Narodowym Programie Mieszkaniowym znalazła się zapowiedź reformy dodatków. W aktualnej formule dodatki dają wsparcie najemcom mieszkań komunalnych i części najemców TBS oraz innych zasobów publicznych. Wysokość wypłacanego dodatku, odnoszona do czynszów komunalnych, nie ma znaczenia dla wynajmujących na rynku. Z kolei dopłaty do czynszów faworyzują wyłącznie użytkowników nowo budowanych zasobów. Dwuelementowy system dopłat do czynszów jest nieefektywny, a koszty socjalnej pomocy mieszkaniowej w formie dodatków mieszkaniowych nie powinny obciążać wyłącznie budżetów gmin.

Potrzebne jest opracowanie i wdrożenie programu wspierania projektów mieszkaniowych w rewitalizacji. Współfinansowanie działań rewitalizacyjnych w sferze mieszkaniowej ze środków funduszy unijnych jest ograniczone, należy więc rozważyć możliwość wdrożenia funduszu wspierającego finansowo projekty mieszkaniowe w obszarach rewitalizacji. Wydaje się, że dobrym rozwiązaniem byłyby regionalne fundusze rewitalizacji przeznaczane na mieszkalnictwo, dostarczające wsparcia w formie nisko oprocentowanych pożyczek na inwestycje budowlano-remontowe oraz dotacji na realizację programów mieszkalnictwa wspomaganego.

Problematyka mieszkaniowa powinna być wprowadzana do rządowych i regionalnych programów strategicznych, w szczególności do Krajowej Polityki Miejskiej i do Długookresowej Strategii Rozwoju Kraju.

Warunkiem koniecznym racjonalnej polityki mieszkaniowej jest dostęp do aktualnych, porównywalnych danych ilościowych i jakościowych. Potrzebujemy bazy informacyjnej do analizy skuteczności i efektywności programów mieszkaniowych na poziomie krajowym i lokalnym. Słabo rozpoznane są przede wszystkim opinie i preferencje obywateli, koszty dostępu do mieszkań i koszty ich użytkowania w układzie sektorów mieszkaniowych i regionów, typów i klas wielkości miast. Przykładem porażki informacyjnej jest lustro czynszowe - system gromadzenia danych o stawkach czynszu. Potrzebne są szerokie badania przekrojowe różnych grup społecznych i wiekowych, pozwalające oddzielić preferencje mieszkaniowe obywateli od ich możliwości finansowych, najczęściej niepozwalających na urzeczywistnienie tych preferencji. Wskazany jest dostęp do informacji z innych dziedzin, by w pełniejszym zakresie rozpatrywać uwarunkowania mieszkaniowe, np. w powiązaniu z dochodami ludzi czy z systemem świadczeń pomocy społecznej.

\section{Bibliografia}

Bryx M., Finansowanie inwestycji mieszkaniowych, Poltext, Warszawa 2001.

Cesarski M., Budżet a mieszkalnictwo i budownictwo społeczne w Polsce. Transformacja i perspektywy " Problemy Polityki Społecznej. Studia i Dyskusje" 2011, nr 15.

Cesarski M., Polityka mieszkaniowa w Polsce w pracach naukowych 1918-2010. Dokonania i wpływ polskiej szkoły badań, Oficyna Wydawnicza SGH, Warszawa 2013.

Cyran R., Wpływ podmiotowych instrumentów polityki mieszkaniowej na koszty utrzymania mieszkania i model zaspokajania potrzeb [w:] Mieszkalnictwo w Polsce. Przyszłość najmu społecznego, red. A. Muzioł-Węcławowicz, Habitat for Humanity Poland, Warszawa 2019, https://habitat.pl/wp-content/uploads/2019/04/Mieszkalnictwo-w-Polsce-Przyszlosc-najmu-spolecznego.pdf. 
Lis P., Polityka państwa w zakresie finansowania inwestycji mieszkaniowych, C.H. Beck, Warszawa 2008.

Jarecki P., Kucharska-Stasiak E., Miklaszewska A., Olbińska K., Wieteska-Rosiak B., Załężna M., Optymalne programy wsparcia budownictwa mieszkaniowego. Analiza efektywności, Warszawski Instytut Bankowości, Łódź 2020.

Mieszkalnictwo społeczne. Raport o stanie polskich miast, red. A. Muzioł-Węcławowicz, K. Nowak, Instytut Rozwoju Miast i Regionów, Warszawa 2018.

Muzioł-Węcławowicz A., Funkcje mieszkaniowe w programach rewitalizacji miast [w:] Współczesne uwarunkowania gospodarowania przestrzeniq - szanse i zagrożenia dla zrównoważonego rozwoju, red. A. Maciejewska, Oficyna Wydawnicza Politechniki Warszawskiej, Warszawa 2014.

Muzioł-Węcławowicz A., Problemy mieszkaniowe Polaków a polska polityka mieszkaniowa [w:] Mieszkalnictwo w Polsce. Analiza wybranych obszarów polityki mieszkaniowej, red. M. Salamon, A. Muzioł-Węcławowicz, Habitat for Humanity Poland, Warszawa 2015, https://forumrozwojulokalnego.pl/uploads/frl/material/file/61/ Mieszkalnictwo_w_Polsce_2015_HABITAT.pdf.

Muzioł-Węcławowicz A., Społeczne budownictwo czynszowe i towarzystwa budownictwa społecznego [w:] Mieszkalnictwo społeczne. Raport o stanie polskich miast, red. A. Muzioł-Węcławowicz, K. Nowak, Instytut Rozwoju Miast i Regionów, Warszawa 2018.

Twardoch A., System do mieszkania. Perspektywy rozwoju dostępnego budownictwa mieszkaniowego, Bęc Zmiana!, Warszawa 2019.

\section{Dokumenty, raporty}

Główny Urząd Statystyczny, Budżety gospodarstw domowych w 2019 roku, Warszawa 2020, https://stat.gov.pl/ obszary-tematyczne/warunki-zycia/dochody-wydatki-i-warunki-zycia-ludnosci/budzety-gospodarstw-domowych-w-2019-roku,9,14.html.

Główny Urząd Statystyczny, Gospodarka mieszkaniowa w 2018 r. Informacja sygnalna, Warszawa 2019, https:// stat.gov.pl/obszary-tematyczne/infrastruktura-komunalna-nieruchomosci/nieruchomosci-budynki-infrastruktura-komunalna/gospodarka-mieszkaniowa-w-2018-roku,14,2.html.

Główny Urząd Statystyczny, Gospodarka mieszkaniowa w 2019 r. Informacja sygnalna, Warszawa 2020, https:// stat.gov.pl/obszary-tematyczne/infrastruktura-komunalna-nieruchomosci/nieruchomosci-budynki-infrastruktura-komunalna/gospodarka-mieszkaniowa-w-2019-roku,14,3.html.

Główny Urząd Statystyczny, Pokolenie gniazdowników w Polsce. Prace eksperymentalne, Warszawa 2020, https:// stat.gov.pl/statystyki-eksperymentalne/jakosc-zycia/pokolenie-gniazdownikow-w-polsce,6,1.html.

Heritage Real Estate Think Tank, Indeks HRE. Indeks koniunktury na rynku nieruchomości w IV kwartale 2020 roku, Warszawa 2021, https://heritagere.pl/wp-content/uploads/2021/03/HRETT-INDEX-4Q-2020.pdf.

Komunikat Prezesa Głównego Urzędu Statystycznego z dnia 25 lutego 2020 r. w sprawie ceny 1 m² powierzchni użytkowej budynku mieszkalnego za IV kwartał 2019 r., https://stat.gov.pl/sygnalne/komunikaty-i-obwieszczenia/lista-komunikatow-i-obwieszczen/komunikat-w-sprawie-ceny-1-m2-powierzchni-uzytkowej-budynku-mieszkalnego-za-iv-kwartal-2019-r-,265,25.html.

Ministerstwo Finansów, Ministerstwo Infrastruktury i Rozwoju, Przegląd wydatków publicznych: Polityka wspierajqca mieszkalnictwo, Warszawa 2015.

Ministerstwo Rozwoju, Pracy i Technologii, Bezpośrednie wydatki budżetu państwa na sferę mieszkaniowq (materiał powielany), Warszawa 2021. 
Ministerstwo Rozwoju, Pracy i Technologii, Efekty rzeczowe pakietu Mieszkanie+ w latach 2016-2020 (stan na 31.03.2021 r.), https://www.gov.pl/web/rozwoj-praca-technologia/narodowy-program-mieszkaniowy.

Ministerstwo Rozwoju, Pracy i Technologii, Raport. Stan mieszkalnictwa w Polsce, Warszawa 2020, https://www. gov.pl/web/rozwoj-praca-technologia/raport-o-stanie-mieszkalnictwa.

Najwyższa Izba Kontroli, Działania administracji publicznej na rzecz zaspokajania potrzeb mieszkaniowych gospodarstw domowych o niskich dochodach. Informacja o wynikach kontroli. 16/2020/P/19/033/KIN, Warszawa 2020, https://www.nik.gov.pl/plik/id,22542,vp,25227.pdf.

Obwieszczenie Wojewody Małopolskiego z dnia 25 września 2020 r. w sprawie ogłoszenia wysokości wskaźnika przeliczeniowego kosztu odtworzenia $1 \mathrm{~m}^{2}$ powierzchni użytkowej budynków mieszkalnych dla miasta Krakowa oraz województwa małopolskiego, z wyłączeniem miasta Krakowa, na okres 6 miesięcy, od dnia 1 października 2020 r. (Dz. Urz. Woj. Mał., poz. 5993), http://edziennik.malopolska.uw.gov.pl/legalact/2020/5993/. Rada Ministrów, Założenia polityki mieszkaniowej państwa, Warszawa 1993.

Uzasadnienie rządowego projektu ustawy o zmianie niektórych ustaw wspierających rozwój mieszkalnictwa, Sejm IX kadencji, druk nr 534, http://www.sejm.gov.pl/sejm9.nsf/druk.xsp?nr=534.

\section{Akty prawne}

Ustawa budżetowa na rok 2021 z dnia 20 stycznia 2021 r. (Dz.U. 2021, poz. 190).

Ustawa z dnia 8 marca 1990 r. o samorządzie gminnym (Dz.U. 2020, poz. 713, ze zm.).

Ustawa z dnia 26 października 1996 r. o niektórych formach popierania budownictwa mieszkaniowego (Dz.U. 2019, poz. 2195, ze zm.).

Ustawa z dnia 21 czerwca 2001 r. o dodatkach mieszkaniowych (Dz.U. 2019, poz. 2133, ze zm.).

Ustawa z dnia 21 czerwca 2001 r. o ochronie praw lokatorów, mieszkaniowym zasobie gminy i o zmianie Kodeksu cywilnego (Dz.U. 2020, poz. 611, ze zm.).

Ustawa z dnia 8 grudnia 2006 r. o finansowym wsparciu tworzenia lokali mieszkalnych na wynajem, mieszkań chronionych, noclegowni, schronisk dla osób bezdomnych, ogrzewalni i tymczasowych pomieszczeń (Dz.U. 2020, poz. 508, ze zm.).

Ustawa z dnia 20 lipca 2017 r. o Krajowym Zasobie Nieruchomości (Dz.U. 2020, poz. 2127, ze zm.).

Ustawa z dnia 22 marca 2018 r. o zmianie ustawy o finansowym wsparciu tworzenia lokali socjalnych, mieszkań chronionych, noclegowni i domów dla bezdomnych, ustawy o ochronie praw lokatorów, mieszkaniowym zasobie gminy i o zmianie Kodeksu cywilnego oraz niektórych innych ustaw (Dz.U. 2018, poz. 756, ze zm.).

Ustawa z dnia 22 sierpnia 2018 r. o ułatwieniach w przygotowaniu i realizacji inwestycji mieszkaniowych oraz inwestycji towarzyszących (Dz.U. 2020, poz. 219, ze zm.).

Ustawa z dnia 10 grudnia 2020 r. o zmianie niektórych ustaw wspierających rozwój mieszkalnictwa (Dz.U. 2021, poz. 11).

Ustawa z dnia 16 grudnia 2020 r. o rozliczaniu ceny lokali lub budynków w cenie nieruchomości zbywanych z gminnego zasobu nieruchomości (Dz.U. 2021, poz. 223). 


\section{Strony internetowe}

https://stat.gov.pl/obszary-tematyczne/przemysl-budownictwo-srodki-trwale/budownictwo/cena-1-m2-powierzchni-uzytkowej-budynku-mieszkalnego-oddanego-do-uzytkowania,8,1.html.

https://tvn24.pl/biznes/nieruchomosci/program-mieszkanie-plus-ile-jest-mieszkan-wybudowanych-a-ile-w-budowie-na-koniec-2020-roku-4944673.

https://www.gov.pl/web/rozwoj-praca-technologia/rzad-dofinansuje-budownictwo-komunalne-w-krakowie.

https://www.gov.pl/web/rozwoj-praca-technologia/wsparcie-inwestorow-w-tym-gmin-w-obszarze-budownictwa-komunalnego-i-spolecznego.

https://www.portalsamorzadowy.pl/gospodarka-komunalna/coraz-wiecej-mieszkan-dla-sredniozamoznych-1-lipca-ruszy-kolejna-edycja-waznego-programu,275507.html. 